\title{
Article \\ Politicization of the Hydropower Dams in the Lancang-Mekong Basin: A Review of Contemporary Environmental Challenges
}

\author{
Richard Grünwald ${ }^{1, *}$, Wenling Wang ${ }^{1, *}$ and Yan Feng ${ }^{1,2} \mathbb{D}$ \\ 1 Asian International Rivers Center, Institute of International River and Eco-Security, Yunnan University, \\ Kunming 650091, China; fengyan@ynu.edu.cn \\ 2 Yunnan Key Lab of International Rivers and Transboundary Eco-Security, Yunnan University, \\ Kunming 650091, China \\ * Correspondence: grunwaldrichard@ynu.edu.cn (R.G.); wangwl@ynu.edu.cn (W.W.)
}

check for updates

Citation: Grünwald, R.; Wang, W.; Feng, Y. Politicization of the Hydropower Dams in the Lancang-Mekong Basin: A Review of Contemporary Environmental Challenges. Energies 2022, 15, 1682. https://doi.org/10.3390/en15051682 Academic Editor: Epari Ritesh Patro

Received: 17 January 2022 Accepted: 9 February 2022

Published: 24 February 2022

Publisher's Note: MDPI stays neutral with regard to jurisdictional claims in published maps and institutional affiliations.

Copyright: (C) 2022 by the authors. Licensee MDPI, Basel, Switzerland. This article is an open access article distributed under the terms and conditions of the Creative Commons Attribution (CC BY) license (https:// creativecommons.org/licenses/by/ $4.0 /)$.

\begin{abstract}
To date, hydropower dams raise numerous interpretations about their impact on the Lancang-Mekong River. While most research studies analyze the negative aspects of hydropower development on people's livelihoods and local environments, the hydropower sector was historically one of the most iconic economic segments facilitating transboundary water cooperation for decades. By using the constructive discourse analysis and critical political ecology approach, the presented text (1) outlines the current environmental narratives over the Lancang-Mekong hydropower development and (2) explores the politicization of the Chinese mainstream dams. The data were collected upon the multi-level content analysis of relevant sources and double-checked with the Lancang-Mekong Cooperation and Conflict Database (LMCCD) monitoring over 4000 water-related events among six riparian countries between 1990 and 2021. Our data show that (i) there is a stark contrast in positive and negative narratives over the rapid hydropower development, (ii) the impact of mainstream dams on the river is more often discussed than that of tributary dams, (iii) implications of the hydropower dams are often interpreted upon the non-traditional research inputs rather than widely accepted studies, and (iv) developing the contradictory arguments through social and public media contributes to greater polarization of the multi-stakeholders' viewpoints in the accountable research dialogue.
\end{abstract}

Keywords: hydropower dams; critical political ecology; Lancang-Mekong River; environmental narratives; water; constructivist discourse analysis; LMCCD

\section{Introduction}

Hydropower development in the Lancang-Mekong Basin has attracted significant media attention for decades. Since the 1950s, when the closer collaboration between four riparian states (Cambodia, Laos, Thailand and Vietnam) had been established, the LancangMekong Basin was considered a highly apolitical and under-utilized international river [1,2]. During the political confrontation between the USA and the Soviet Union [3,4], there were limited ways to promote peace among nations and lift out Southeast Asian states from poverty. Apart from providing development aid and other assistance [5-7], hydropower development slowly became a politically acceptable and economically viable solution for ensuring some sort of pragmatic and long-lasting cooperation that endured even the horrors of the Cold War era. To replicate the success of the hydropower development, many water cooperation mechanisms (Mekong River Commission (MRC), Greater Mekong Sub-region (GMS), ASEAN Mekong Basin Development Cooperation (AMBDC), etc.) have been launched since the end of the Cold War to follow the legacy of exceptional water cooperation. However, such open support for advancing the basin development was not fully accompanied by good water governance principles [8-10] and deep consideration of the complex hydro-meteorological changes.

While many hydrological studies [11-13] and international scientists [14-16] consistently warn against various negative consequences associated with the rapid hydropower 
development, most attention was paid to the Chinese mainstream dams [17-19] and several controversial water projects in downstream countries, particularly the Lower Sesan II, Xayaburi, Xepian-Xenamnoy and Yali Falls dams [20-23]. Perhaps the biggest politicization of the hydropower dams arose after April 2020, when a team of two researchers published a study regarding the negative impact of upstream mainstream reservoirs on the natural water flow [24]. The so-called Eyes on Earth Study (EoE Study) received unusual media attention for legitimizing the anti-dam narratives $[25,26]$ and became widely accepted by a plethora of multi-stakeholders despite the strong criticism for simplification and misinterpretation of the research findings [27-30]. On the other hand, by escalating the pressure on the water data sharing, two additional hydrological monitoring initiatives addressing the Lancang-Mekong hydrological changes have been introduced [31,32]. Contradictory to the traditional view where both the Lancang-Mekong Water Cooperation and Information Platform (LMWCIP) and Mekong Dam Monitor (MDM) were driven by the politicization of the EoE Study, we believe that the behavioral change in existing transboundary water cooperation has not yet been achieved due to the lack of high-quality research inputs and shallow involvement of the downstream multi-stakeholders in the negotiation process.

As our literature review shows, the perception of the hydropower dams changes over time. Historically, the hydropower dams were considered a symbol of national pride and an archetype of the technical progress maximizing the benefits from the local environments [33-35]. With the new technologies and technical possibilities, the hydropower sectors underwent the gradual transition towards the grandiose multi-purpose dams dealing with all tangible water challenges. Moreover, besides the massive investments from foreign donors and other financial institutions, the rapid hydropower development was backed by the "Mekong Spirit" narrative as an ideological tool for facilitating regional water cooperation at all costs [36,37]. The popularization of hydropower development continued until the early 1990s. Since then, the optimistic view on the hydropower sector reached its peak and was widely considered a cheap, renewable and clean source of energy promoting the comprehensive basin development [38,39]. However, such politicization of the hydropower dams was redeemed by the pacification of the unwanted critique $[40,41]$ and hiding most of the hydrological data over the water projects $[39,42]$. While the initial idea was to promote the transboundary water cooperation by all means and marginalize all undesirable civil movements blocking the path toward joint prosperity, the long-term legitimization of the hydropower dams in a non-transparent environment created a highly volatile space for corruption and contributed to greater research uncertainty over these projects. Many dams were then built upon the shallow hydrological studies and controversial impact assessments to justify the hydropower development [43-45], including those economically infeasible, socially insensitive or environmentally troublesome projects [46,47].

By using the constructive discourse analysis and critical political ecology approach, the presented text (1) outlines the current environmental narratives over the Lancang-Mekong hydropower development and (2) explores the politicization of the Chinese mainstream dams. The paper is divided into a few parts. The connection between critical political ecology and politicization of hydropower dams is explained in Section 2. The data sources and methodology of research are presented in Section 3. The research results from the extensive literature review are demonstrated in Section 4. In Section 5, we discuss the research findings and make some conclusions regarding the current discourse practices.

\section{Critical Political Ecology and Politicization of Hydropower Dams}

The political ecology was developed in the late 1960s as an interdisciplinary theoretical approach analyzing the complex interaction between humans and nature $[48,49]$. Unlike the traditional environmental theories examining the degree of utilization of natural water resources facilitating sustainable human development, political ecology investigates how multi-stakeholders construct, disseminate and justify various arguments during the negotiation process [21,50-52]. While most attention is paid to the official speech acts in which the policy-makers confront, interpret and legitimize desirable practices [53-55], the control over 
natural resources is primarily driven by tangible factors rather than biophysical ecological aspects [56]. In contrast with political economy and geopolitics, the political ecology considers any challenge as a window of an opportunity for re-considering the research stereotypes by advancing the research dialogue over the non-traditional environmental issues [57-59]. To examine the asymmetry between the various versions of the truth and clarify the tendencies for rejecting the opposite interpretations [60,61], we studied the contradictory scientific and non-scientific viewpoints related to the Lancang-Mekong hydropower development. Compared to the Middle East and Central Asian international rivers, where hydropower development is often associated with water-scarcity conflicts [2,62], the Lancang-Mekong Basin disputes are generally triggered by enlarging the pie of benefits from abundant shared waters and incompatibility of national interests between different political systems $[63,64]$.

\subsection{Politicization Strategies}

By drawing on discursive framing theories and the critical hydropolitics [65-69], there can be identified several mechanisms stimulating the actual outcomes in the transboundary water interaction. As is shown in Figure 1, both scientists and non-scientists have numerous options on how to affect hydropower development. First, there are the coercive mechanisms, which can be described as a subset of actions requiring physical force and other forms of intimidation. Unlike the local water wars or various acts of water terrorism [62,70], the coercive power is standardly exercised through imposing economic sanctions, adopting various trade embargos or using military force to blockade the geostrategic chokepoints. Yet, in the Lancang-Mekong Basin, this type of mechanism was mainly demonstrated by multiple non-participatory actions or threatening the opponents by adopting various retaliatory actions $[37,71,72]$. Second, the leverage mechanisms represent the group of activities delimiting the influence of other multi-stakeholders. Whereas the downstream governments use this mechanism to multiply the tangible benefits from foreign donors, the regional powers mobilize their funds and re-distribute their development aid to form stronger alliances and ensure the balance of power in the region $[39,65]$. Third, there are transformative mechanisms that re-frame the existing water knowledge and re-interpret the contested water issues. Such behavioral change is traditionally influenced by raising public awareness about controversial water projects, co-producing the water knowledge with civil society and improving the access and scope of the shared hydrological data through remote sensing $[25,68,73]$. However, due to the unequal capacities of the riparian governments to produce their water knowledge, a strong reliance on the third party's datasets and harmonizing the national interests according to the Mekong Spirit of water cooperation [39,74], the actual debate over the sustainable hydropower development only enlarged the number of multi-stakeholders and institutionalized the political labelling rather than encouraging the actors to initiate the structural reforms. Hence, regardless of the clash of research viewpoints among researchers to make better science (contestation) and the increasing number of the communication platforms to address the multi-stakeholder interests (compliance), it is the enlarging pie of research uncertainties that reiterate the existing water narratives and cement the current status quo between scientists and nonscientists.

\subsection{Politicization of Science}

In the post-truth era, the line between science and politics can sometimes be very blurry. While putting faith in technocratic solutions present one of the viable strategies for how to depoliticize the research discourse and address the unsatisfactory political responses [75-77], both the scientization of politics and the politicization of science are neither good nor bad [78-80]. What changed is the way multi-stakeholders interpret their visions and negotiate with other actors. For scientists, it is the "science without politics" [81] that ensures the exclusivity of the academic community and paves the path to unlimited research outlooks [82]. For non-scientists, it is the required time, expected costs and simplicity of the scientific conclusions that are more important to decide whether to 
continue with certain water management practices or not $[25,83]$. This is also the case for the Lancang-Mekong hydropower dams. As it shown in Figure 2, most of the mainstream hydropower dams are distributed in the Upper Lancang-Mekong Basin which raise concerns about the sustainability of the river. Such rumours can be notably identified when the unusual severe droughts $(2004,2015,2019)$ and sudden floods $(2008,2014)$ hit the downstream countries $[26,84,85]$. Despite the fact that many scholars believe that these water insecurities were mainly driven by hydro-meteorological reasons rather than man-made projects [86-88], calling the Chinese hydropower dams as the main culprit for amplifying the environmental risks is a very popular preconception in recent years. Whenever both scientists and non-scientists applied this narrative to emphasize China's utilitarianism [89,90] and other geostrategic intentions in Southeast Asia [71,91], this narrative was more often used to transfer various responsibilities for joint river management and multiply the fears from upstream countries $[16,17,21]$.

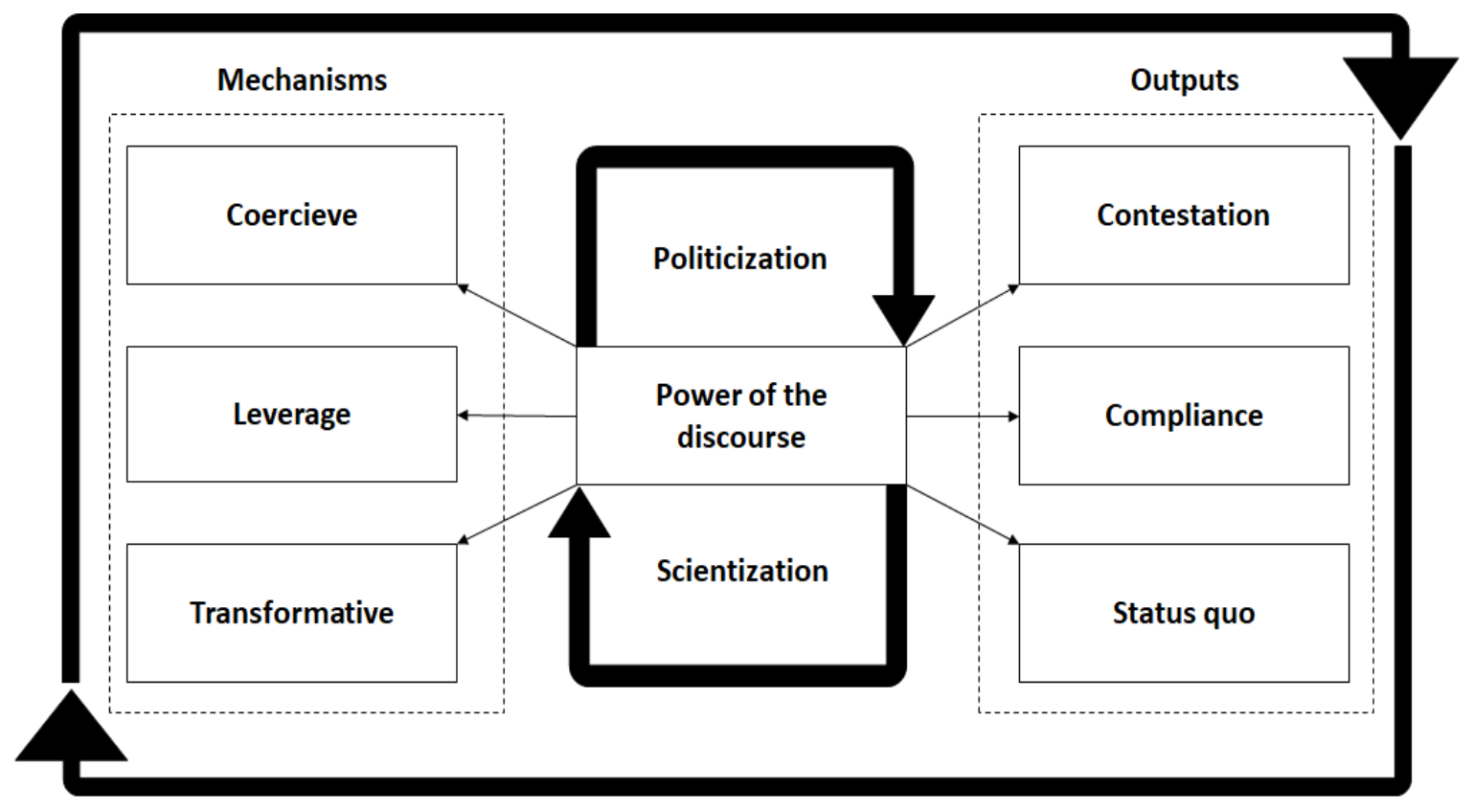

Figure 1. The power of the discourse over hydropower dams-key mechanisms and outputs.

Until 2016, many foreign observers claimed that China's government would highly unlikely join any initiative that would require further regulations of the upstream hydropower development $[15,37,39]$. The gradual behavioral change of China's government in its engagement in transboundary water governance appeared after the establishment of the Lancang-Mekong Cooperation (LMC) in early 2016. China's government not only committed to promote joint basin development and share more information about its water operations but also to release more water from upstream dams to alleviate the seasonal droughts $[93,94]$. Other progress associated with the growing politicization of Chinese hydropower dams can also be found in terms of facilitating closer research collaboration with the MRC since late $2019[95,96]$ and strengthening the policy-research dialogues addressing the current water insecurities [97,98]. Nevertheless, despite the prolonged communication shortcomings, historical prejudice, and other aspects undermining the trust among multistakeholders, changing the quality and quantity of shared waters is far beyond the capacity of Chinese mainstream dams $[30,87,99]$. 


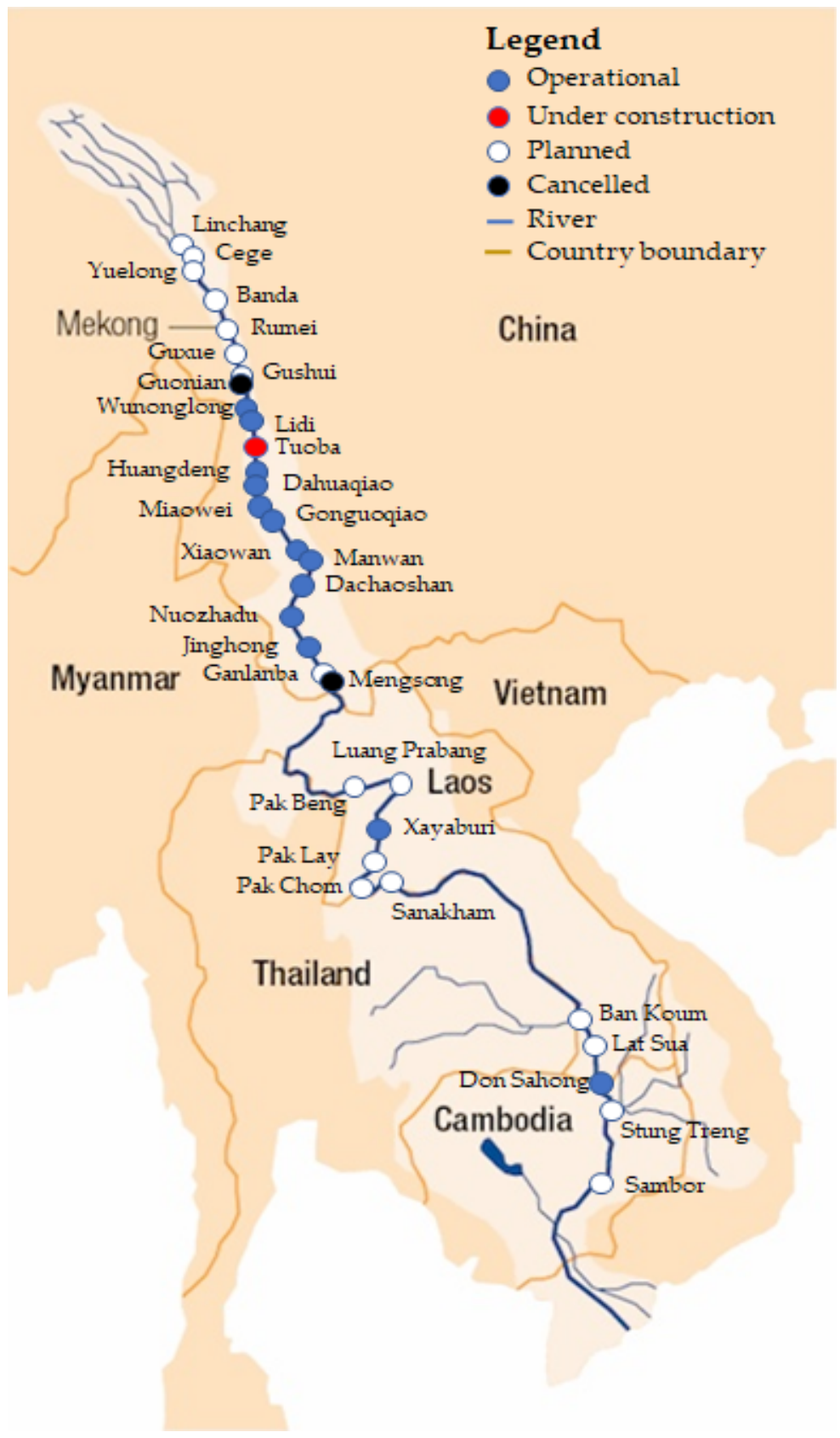

Figure 2. Current and planned hydropower dams in the Lancang-Mekong Basin [11,12,92].

\subsection{Scientization of Politics}

In the name of science, many multi-stakeholders propose various solutions for ensuring sustainable hydropower development. So far, the plethora of multi-stakeholders seem to be in favour of the small-scale hydropower development [100], improving the existing hydropower operations by undertaking various technical reforms [101-103] and enhancing the capacity building of the dam operators [21,104]. Other forms of satisfaction present the better transparency of the operational hydrological data [2,22,34], conducting more detailed socio-environmental assessments of the tributary dams [11,12] or improving the multi-track research dialogue through good water governance $[105,106]$. Nevertheless, the scientization of politics may not necessarily mean salvation for scientists. Instead, it may create the environment formalizing the power inequalities among multi-stakeholders and legitimizing the preferable knowledge [107]. In fact, scientists are not neutral arbiters nor privileged actors since their values and interests are highly influenced by their professional 
backgrounds $[108,109]$. A similar misconception also presents the strong faith in institutionalization and the legal bindingness of the water cooperation $[2,105,110]$, where not every agreement or cooperation mechanism possesses the capacity to facilitate further research dialogue $[69,72,111]$.

Yet, instead of elaborating the importance, capacities and responsibilities of the relevant multi-stakeholders involved in the decision-making process $[23,39,44]$, we briefly designed the conceptual scheme explaining the key aspects affecting the behavioral change towards hydropower development (Figure 3). First, there are the biophysical, economic and political drivers that stimulate multi-stakeholder dialogue and indicate if it is feasible to build or not to build the particular water project [65]. Second, there are the inputs from the scientists and non-scientists that determine the fate of the proposed hydropower project. During the negotiation, the multi-stakeholders express different expectations, formulate various demands and demonstrate multiple needs to safeguard their interests [33]. Although the material, bargaining and ideological powers among multi-stakeholders significantly vary [112], it is the actor's performance and form of communication that justify whenever the ratio between the tangible benefits and potential costs is politically acceptable. Third, regardless of the decision of the policy-makers and planned itinerary of the dam construction, any water infrastructure project can be potentially re-designed, postponed and even cancelled according to the actual needs and demands of the multi-stakeholders. However, once the hydropower dam is completed, the potential decommissioning of the hydropower projects can be politically, economically and ecologically troublesome, especially for developing countries, which may not be able to afford to cancel the existing contracts $[39,71,102,103]$.

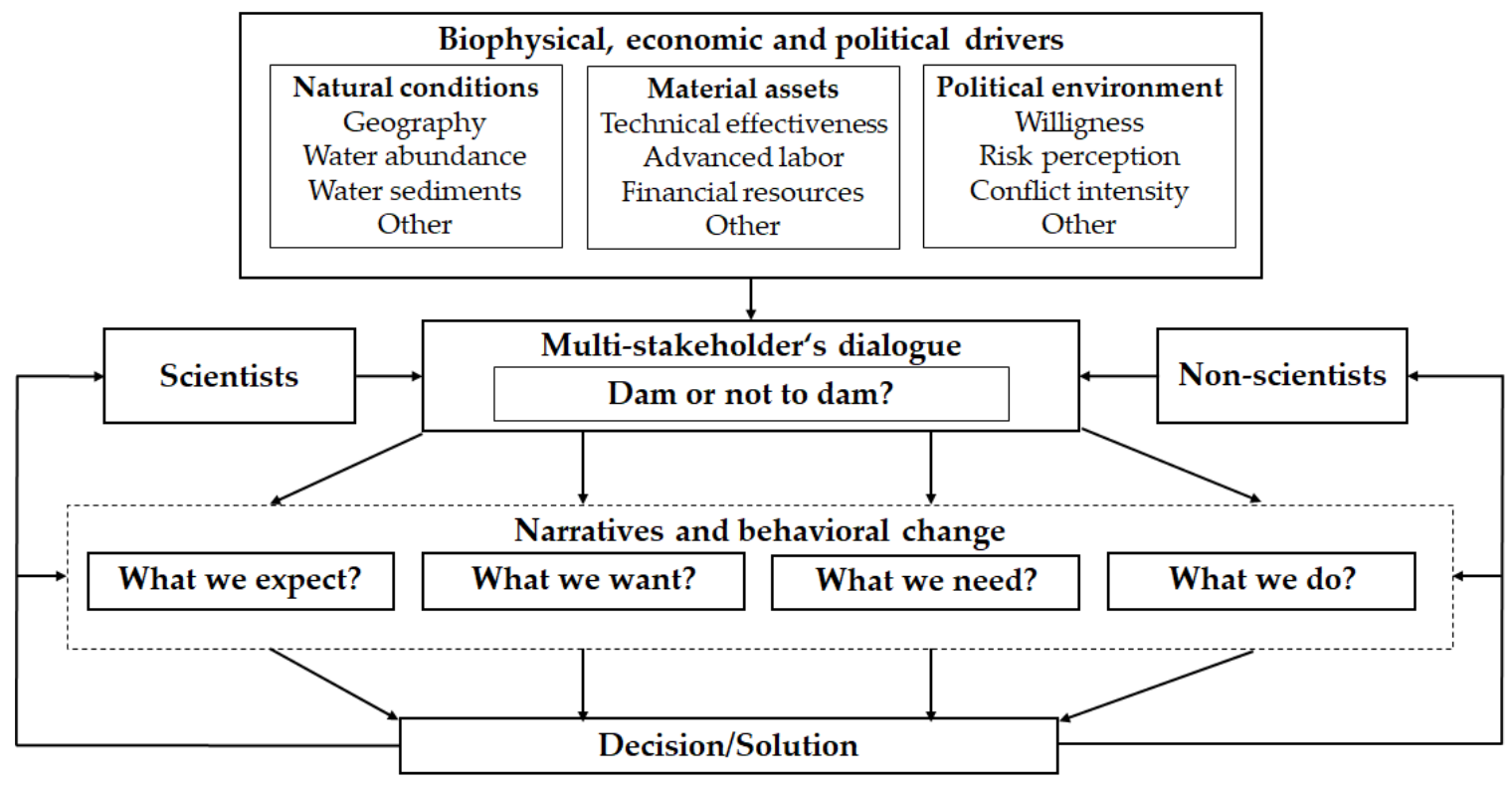

Figure 3. Conceptual scheme highlighting the systemic impact of the hydropower development.

\section{Methods and Data}

The presented paper uses the constructivist discourse analysis to investigate the argumentation patterns over the water-related issues $[113,114]$. Compared to sentiment analysis, which is getting increasingly popular in socio-hydrology $[115,116]$, the constructivist discourse analysis is more suitable for exploring the multi-stakeholder performance by re-considering their beliefs, values and other post-positivists aspects [117]. Moreover, whenever the hydropower dams are interpreted positively or negatively, a holistic context clarifying the different versions of reality help to deconstruct the current water narratives and re-define interconnected actions in human-water interaction. The data for this research were derived from the Lancang-Mekong Cooperation and Conflict Database (LM- 
CCD) tracking the multifarious water-related events between six riparian states within the last 31 years (1990-2021). Unlike other water databases (e.g., Water Conflict Chronology Database, International Water Dispute Database), the LMCCD records over 4000 publicly accessible full-text sources. This helped us to overview the deviations of widely accepted interpretations over the Lancang-Mekong hydropower dams and revise the multi-stakeholder inputs in the last two years when the politicization of the hydropower dams re-emerged.

As is shown in Table 1, we outlined several parameters and assigned multiple keywords to retrieve the basic information about the past and current development pathways in the Lancang-Mekong hydropower development. Since the majority of LMCCD datasets were collected through the multi-level analysis of official and secondary documents over specific water issues [25,118] and already calibrated (i.e., excluded the duplicated, unverifiable, confidential and unpublished sources), using the traditional positivist methods (e.g., comparison of the most frequent references and the number of repetitive words) could potentially produce some biases in our research conclusions. Hence, we undertook a pre-screening of the LMCCD datasets before April 2020 and selected 1020 literature sources regarding the politicization of Chinese hydropower dams in the last 18 months (April 2020-September 2021). To enhance the scope and deepness of the contemporary interpretations, we added several keywords associated with hydropower development and other relevant references polarizing the current research dialogue. On the other hand, more research needs to be conducted to acknowledge the "close-door events" (e.g., panel discussion, workshops, regional meetings with multi-stakeholders) and other micro-events (e.g., local protests, letter of concerns, filled lawsuits) to fill the information gaps.

Table 1. List of searching parameters and keywords for retrieving data from the LMCCD.

\begin{tabular}{cl}
\hline Parameter & \multicolumn{1}{c}{ Keywords } \\
\hline Object & Hydropower dam, hydropower development, dam \\
\hline Context & $\begin{array}{l}\text { Governance, diplomacy, cooperation, conflict, management, data sharing, floods, droughts, } \\
\text { upstream, protest, fishery, agriculture, climate change }\end{array}$ \\
\hline State & China, USA, Myanmar, Thailand, Laos, Cambodia, Vietnam \\
\hline Actor & $\begin{array}{l}\text { Construction company, energy company, financial institution, assistant agency, bank, River } \\
\text { Basin Organization, NGO }\end{array}$ \\
\hline \multirow{2}{*}{ Other } & $\begin{array}{l}\text { Manipulation of water flow, water aggression, hydro-hegemony, water peaking, Eyes on } \\
\text { Earth, Lancang-Mekong Cooperation, Mekong-U.S. Partnership, Mekong River } \\
\text { Commission, communication, geopolitics, security, politics }\end{array}$ \\
\hline
\end{tabular}

To ensure information consistency, the majority of data were derived from Englishwritten sources rather than regional languages. The only exception presents a few Chinese official speech acts and several secondary sources that were repeatedly quoted and translated in various official and public media. In addition, we included the references from official MDM accounts on Twitter and Facebook media, which were frequently used for accelerating the water notification and simplifying the research jargon for a broad audience. Although these social media inputs can be considered less relevant compared to the other literature sources, we noticed some unusual nuances and other irregularities with the content shared through the official MDM websites. As mentioned earlier, the purpose of the constructivist discourse analysis and critical political ecology is not to distinguish between popular and unpopular claims [61] but rather to highlight the contemporary mainstream interpretations and indicate how the politicization of hydropower dams affect the accountable research dialogue. To fill the information gaps about current discourse practices stimulating the negotiation over the Lancang-Mekong dams, we divided the narratives into three groups according to the type of actor. First, there are the policy inputs that are derived from the official speech acts to monitor the actual changes in the political rhetoric of the state representatives. Second, there are the research inputs represented by various research assessments from interdisciplinary scientists and other experts to 
explore the plurality of research viewpoints on hydropower development. Third, there are the media inputs that include the newspaper articles sharing the expert opinions and other concerns from the civil society to examine the public perception of the current water disputes. However, more research needs to be conducted to better conceptualize the politicization of water science [119] and multi-stakeholder attitudes towards hydropower development [22,40,81,120].

\section{Results}

\subsection{Overview of Contemporary Water Narratives}

Our data show that there are numerous positive and negative narratives associated with hydropower development (Table 2). So far, most of the proponents emphasize the short-term regulatory positives $[88,99,121]$ and long-term benefits from optimizing the utilization of shared waters on a collective basis $[38,112,122,123]$. Depending on the hydropower operations, location and natural conditions, many multi-purpose hydropower dams can positively facilitate water navigation, improve the efficiency of energy generation and provide other tangible benefits for riparian countries [124-127]. Other direct benefits may range from various compensations for the resettled communities [127,128] to regular water releases from water dam reservoirs, which are enhancing agricultural production $[129,130]$ and reducing the cost of severe droughts $[90,131]$. Indirectly, the hydropower development is often accompanied by intense pressure on technical and technological innovations [11,12,46,118], deepening the joint transboundary water management $[21,37,132]$ and improving the transparency of the operational hydrological data $[31,133,134]$. Others indirect benefits of hydropower development include decreasing costs of generated electricity, promoting the energy grid stability, enhancing technical safety, facilitating cross-border trade with energy production and delivering electricity to remote areas $[21,135,136]$. In addition, the strong lobby for hydropower development is continuously developing the discussion about the other alternative source of energies $[137,138]$ and motivating both policy-makers and other multi-stakeholders to re-consider economically infeasible and other controversial large-scale water projects $[20,21,139]$, including the Non-Navigational Channel Improvement Project, which was cancelled in February 2020 [140,141].

However, such regulatory benefits are not always being safeguarded. In fact, the frequent water regulations may reduce the influx of water sediments, decrease the biodiversity of animal and plant species, and contribute to soil erosion, particularly in Cambodia and Vietnam, which are mostly affected [14,19,21,142,143]. Other direct challenges connected with the water peaking phenomenon $[88,99,144,145]$ include sudden water fluctuations $[44,146,147]$, changing water color, and deteriorating ecosystem health due to the algae bloom $[148,149]$, which produce methane emission caused by stored carbon in bottom sediments [150,151] and accelerate other cumulative environmental processes [152-154]. Because many negative consequences occurred as a by-product of multiplying the benefits [155-157] and securing the hydropower development in local environments [40,71,158], the large-scale water projects attract significant media attention and numerous speculations beyond the data $[24,25,159,160]$. 
Table 2. Summary of the main consequences of the Lancang-Mekong hydropower dams.

\begin{tabular}{ll}
\hline \multicolumn{1}{c}{ Positives } & \multicolumn{1}{c}{ Negatives } \\
\hline Energy generation & Water quantity \\
- Producing cheaper electricity & $\bullet \quad$ Decline of water sediments \\
- Improving energy grid scope and stability & $\bullet \quad$ Changing the river landscape \\
\hline$\quad$ Facilitating the international trade & Water quality \\
\hline Flood and drought management & $\bullet \quad$ Affecting the water safety \\
- Mitigating seasonal flood costs & $\bullet \quad$ Decreasing the water temperature \\
- Snsuring reasonable water flow & $\bullet \quad$ Influencing the water color ${ }^{1}$
\end{tabular}

\section{Irrigation}

- $\quad$ Promoting food security

- $\quad$ Diversifying agriculture production

- Mitigating soil erosion

\section{Environmental issues}

- Aquatic biodiversity degradation

- Changing the bird life cycle

- Compounding water insecurities ${ }^{2}$

\section{Water navigation}

- $\quad$ Easing navigability of the river

- Securing the water transportation

- Facilitating the cross-border trade

\section{Social issues}

- Inadequate compensations

- Improper relocation policies

- Communication shortcomings

\section{Improving local livelihood}

- Building critical local infrastructure

- Resettlement compensations

- Promoting local economies
Legal issues

- Ineffective water governance

- Non-binding water management

- Underdeveloped code of conduct

\section{Other}

- Technical and technological innovations

- Data sharing cooperation

- Promoting alternative sources of energy

- $\quad$ Re-considering water project development

\section{Other issues}

- Physical water project safety

- Vague technical solutions

- Dam re-sizing and decommissioning

- $\quad$ Slow and inconclusive research process

${ }^{1}$ To date, there is no definite research consensus on this issue. For further information, see $[11,12,99,145] ;{ }^{2}$ To date, there is no definite research consensus on this issue. For further information, see $[25,26,30]$.

Perhaps the most significant area of public awareness raises the indirect costs of the hydropower dams and the capacity of multi-stakeholders to ensure sustainable hydropower development. While many technical solutions, such as fish-friendly hydropower turbines, various fish-restoration projects and adaptive fish passage, have already been applied to mitigate the environmental cost of hydropower dams, their effectiveness was repeatedly questioned due to the rich aquatic biodiversity and insufficient testing [121,122,161]. Similar difficulties can also be found in numerous cases of inadequate compensations for relocated communities, lack of legal bindingness of regional water cooperation mechanisms, uncertain physical security of the water reservoirs or persisting communication shortcomings among multi-stakeholders [21,22,37,70]. Apart from the water mismanagement, many observers consider the absence of the re-sizing and decommissioning of the existing dams [12,13], weak legal responsibilities for non-state actors [23,71,111], abstract solutions and the slow research process as hotspots of new water disputes that may trigger further political tension among multi-stakeholders [25]. Hence, considering the current advancements in ensuring sustainable hydropower development, the political willingness and accountable research dialogue will be the key to initiating the structural behavioral changes towards the hydropower sector. 


\subsection{Politicization of Chinese Hydropower Dams}

In April 2020, the Eyes on Earth in collaboration with the Lower Mekong Initiative (LMI) and other partners published a hydrological study analyzing the actual impact of the upstream hydropower dams on the natural water flow [24]. The authors concluded that since 2017, the Miaowei (1400 MW), Huangdeng (1900 MW), Dahuaqiao (900 MW), Lidi (400 MW) and Wunonglong (990 MW) dams started to compound the alteration of the natural flow, which presumably compounded the dry season in early 2019 [24]. While the politicization of the EoE Study conclusions raised relevant concerns and served as a basis for the MDM [32], there is still no consensus on the EoE Study empirical findings. Yet, besides the lack of the peer-review process, exclusion of the left-bank tributaries, marginalization of the complex hydro-meteorological conditions and misinterpretation of the MRC hydrological data $[27,28,30]$, the EoE Study has become a subject of numerous contradictory commentaries that polarize both scientific and non-scientific communities until now $[25,26]$. After reviewing the 1020 literature sources in the last 18 months (April-September 2020), we outlined several rhetorical patterns politicizing the Chinese mainstream dams.

\subsubsection{Policy Inputs}

As shown in Table 3, most of the policy-maker inputs regarding the politicization of Chinese mainstream dams was made by the Chinese and US state officials rather than downstream governments. In fact, since both superpowers in late 2020 addressed the politicization of hydropower dams through additional hydrological monitoring platforms [31,32], the dialogue over the actual impacts of the hydropower dams was mainly oriented on justifying and refuting the EoE Study conclusions. The transition from expressing mild concerns and joint efforts for deepening the existing water cooperation was quickly substituted by escalating political accusations and other claims beyond the water context [162-169]. The US political rhetoric has become more aggressive and loaded with various euphemisms to trigger the emotional response from civil society and anti-dam movements [25]. Combined with the public sensitivity to any alteration of the water flow, long-term marginalization of the negative implications of the hydropower dams and a lack of systemic regulation of the hydropower development, the US official responses oscillated between offensive and defensive rhetoric. Surprisingly, while the US official discourse frequently put the EoE Study conclusions into the geopolitical context and with the references of newly established Mekong-U.S. Partnership (MUP) [170], the US official policy inputs strongly relied on the Eyes on Earth [171,172] and Stimson Center inputs [173] without further consideration of the critical research responses [27-29].

In contrast, the Chinese official responses towards the EoE Study were initially more conservative due to scheduled advancements in transboundary water cooperation [92-94] and the presence of various MRC science-based assessments, including the response report on the EoE Study [30]. For Chinese state officials, the EoE Study was perceived as another "problem-solution" scheme in which no matter how much effort will be put in addressing these concerns, the actual outcome of such progress is highly uncertain. From marginalizing the positive effects of water release from Jinghong hydropower dam in March 2016, more hydrological data were shared to comply with the commitments that are not operationalized by the downstream countries to demonstrate various forms of dissatisfaction with Chinese actions regardless of whether the initial inquiry was fulfilled or not $[39,88]$. 
Table 3. List of policy-makers inputs de/politicizing the Chinese mainstream dams *.

\begin{tabular}{|c|c|c|}
\hline US Policy-Makers & Chinese Policy-Makers & Other Policy-Makers \\
\hline Michael Pompeo commentary $(4 / 20)$ & Shuang Geng commentary $(4 / 20)$ & Thailand unofficial commentary $(4 / 20)$ \\
\hline Michael DeSombre commentary $(4 / 20)$ & Keqiang Li commentary $(4 / 20)$ & 24th MRC Dialogue Meeting $(10 / 20)$ \\
\hline David R. Stilwell commentary $(6 / 20)$ & LMC JWG Meeting on LMWCIP $(5 / 20)$ & Mekong People's Council Forum $(12 / 20)$ \\
\hline Michael Pompeo commentary $(9 / 20)$ & 3rd LMC Leader's Meeting $(8 / 20)$ & Vietnam unofficial commentary $(12 / 20)$ \\
\hline David R. Stilwell commentary $(9 / 20)$ & Keqiang Li commentary $(8 / 20)$ & Prak Sokhonn commentary $(3 / 2021)$ \\
\hline 1st MUP Meeting $(9 / 20)$ & LMC Water Symposium $(9 / 20)$ & Sreng Sataro commentary $(5 / 21)$ \\
\hline David R. Stilwell commentary $(10 / 20)$ & Lijian Zhao commentary $(9 / 20)$ & 4th MRC Expert Group Meeting $(9 / 21)$ \\
\hline Indo-Pacific Conference $(10 / 20)$ & 2nd LMC JWG Meeting on water $(9 / 20)$ & 25th MRC Dialogue Meeting (9/21) \\
\hline David R. Stilwell commentary $(12 / 20)$ & 1st LMC Water Resources Meeting (10/20) & \\
\hline David R. Stilwell commentary $(12 / 20)$ & LMC Workshop on Hydropower $(10 / 20)$ & \\
\hline 1st FLM Policy Dialogue (1/21) & LMWCIP has been launched $(11 / 20)$ & \\
\hline Ned Price commentary $(2 / 21)$ & Zhaohui Luo commentary $(11 / 20)$ & \\
\hline W. Patrick Murphy commentary $(2 / 21)$ & Zhaohui Luo commentary $(11 / 20)$ & \\
\hline Atul Keshap commentary $(3 / 21)$ & Chunying Hua commentary $(12 / 20)$ & \\
\hline EWC-MUP conference report $(3 / 21)$ & Wenbing Wang commentary $(12 / 20)$ & \\
\hline MUP Track 1.5. Policy Dialogue (3/21) & LMWCIP-MRC Water Data Meeting $(3 / 21)$ & \\
\hline Kamala Harris commentary $(4 / 21)$ & Chungying Hua commentary $(3 / 21)$ & \\
\hline W. Patrick Murphy commentary $(6 / 21)$ & LMC Delegates hydropower tour $(4 / 21)$ & \\
\hline 1st MUP Senior Official Meeting (6/21) & 6th LMC Foreign Minister Meeting (6/21) & \\
\hline MUP training $(7 / 21)$ & Wang Yi commentary $(6 / 21)$ & \\
\hline W. Patrick Murphy commentary $(8 / 21)$ & Wenbin Wang commentary $(6 / 21)$ & \\
\hline 2nd MUP Ministerial Meeting $(8 / 21)$ & Keqiang Li commentary $(9 / 21)$ & \\
\hline \multicolumn{3}{|l|}{ FLM Ministerial Meeting $(8 / 21)$} \\
\hline 1st MUP Track 1.5. Policy Dialogue $(9 / 21)$ & & \\
\hline
\end{tabular}

* The date abbreviations have been shortened according to respective month and year. For example, an event in September 2021 is re-written as a (9/21). Other abbreviations represent the Friends of the Lower Mekong (FLM) and Joint Working Group (JWG).

Nevertheless, soon after the strong public media outcry and growing speculations over the Chinese mainstream dams emerged [25], the Chinese state representatives repeatedly advised the US government to stick to the facts and quote the EoE Study findings with caution $[167,169]$. However, because of the series of communication shortcomings of the LMWCIP, particularly in terms of the understudied water color phenomenon [174-176] and underdeveloped notification schemes over the upstream water operations [177,178], the Chinese officials were unable to pay more attention to the transboundary water issues until mid-2021 as a result of the ongoing coronavirus pandemic $[179,180]$. Nevertheless, compared to the US depoliticization strategies supporting various public-science meetings and other initiatives engaging the non-state actors in the decision-making process [181-183], the Chinese state officials seem to put more faith in advancing the collaboration with regional partners and strengthening the joint research investigations, particularly with the MRC $[184,185]$. Therefore, despite both the US and Chinese officials expressing their willingness to facilitate closer regional water collaboration and enhance the joint research investigations based on the robust empirical facts, the accountable research dialogue remains highly fragmented and driven by tacit proclamations without clear solutions. While some observers may consider the perpetual rhetorical battles over the EoE Study conclusions and spreading political distrust towards the undesirable research narratives as foreplay for how to delineate the sphere of influence between LMWCIP and MDM, the shallow involvement from the downstream governments is probably caused by balancing the power in the region and keeping the distance from the potential retaliatory actions [71,91].

\subsubsection{Research Inputs}

As Table 4 shows, the depoliticization of the research dialogue over the Chinese mainstream dams was predominantly driven by international scientists and other research institutions $[27,28,30,186,187]$. Apart from the Eyes on Earth, the most significant public awareness about the adverse effects of upstream hydropower development on the river has been attracted by various US scientific commentaries. So far, most of the US research inputs have been shared through multiple interviews [188-190]. The rest of the US inputs were replicated through the MDM social media (i.e., Facebook and Twitter) and numerous science-public forums [191-193]. In addition, since no high-impact research article has been published to support the EoE Study conclusion [25], the only operationalization of 
the EoE Study findings can be found at the MDM. Compared to the LMWCIP, which provided three announcements related to the temporal water fluctuations as a result of the planned hydropower maintenance [194-196], the MDM submitted twenty alerts and issued dozens of comments through their official websites. Followed by the major update of the MDM in June 2021 dealing with the biases in datasets [172] and improving the MDM performance by promoting citizen science [197,198], the MDM proved to be a very progressive instrument in fostering comprehensive hydrological monitoring. This provides an essential step towards changing the US research mindset towards the Chinese upstream dams. However, because the MDM presents an exclusive research platform with no legal mandate and primarily utilizes the remote sensing methods and downstream civil society to fill the information gaps [199], the high-quality research inputs and willingness to address the existing shortcomings remain shallow [26]. Another challenge is present in the use of social media, where MDM Twitter and Facebook accounts tend to provide rapid reviews of the current situation and other notifications at the expense of high-quality research inputs. Such simplification of the MDM research content and using the non-scientific jargon then sometimes lead to overstatements and create various speculations beyond the actual data $[26,27]$.

Table 4. List of research inputs politicizing and depoliticizing the Chinese mainstream dams *.

\begin{tabular}{|c|c|c|}
\hline US Researchers & Chinese Researchers & Other Researchers \\
\hline EoE Study $(4 / 20)$ & Tsinghua University Study $(7 / 20)$ & MRC unofficial commentary $(4 / 20)$ \\
\hline SC commentary $(4 / 20)$ & Lu Xing commentary $(7 / 20)$ & MRC report on EoE Study $(4 / 20)$ \\
\hline SC researcher commentary $(4 / 20)$ & Tsinghua University commentary $(8 / 20)$ & AMPERES commentary $(4 / 20)$ \\
\hline EoE research commentary $(4 / 20)$ & Zhong Yong commentary $(10 / 20)$ & FCCT discussion on EoE Study $(4 / 20)$ \\
\hline$S C$ researcher commentary $(5 / 20)$ & Xingjun Yu commentary $(12 / 20)$ & Aalto University commentary $(4 / 20)$ \\
\hline SC and EoE researcher commentary $(5 / 20)$ & 1st LMWCIP announcement $(1 / 21)$ & CU Dialogue Forum 4 Mekong $(7 / 21)$ \\
\hline SC researcher commentary $(6 / 20)$ & 3rd Water Security Forum $(4 / 21)$ & MRC report on Chinese dams $(8 / 20)$ \\
\hline SC-EoE researcher commentary $(7 / 20)$ & 2nd LMWCIP announcement $(7 / 21)$ & CU seminar on the EoE Study $(8 / 20)$ \\
\hline SC researcher commentary $(1 / 21)$ & 3rd LMWCIP announcement $(7 / 21)$ & China-Southeast Asia webinar $(9 / 20)$ \\
\hline 1 st MDM announcement $(1 / 21$ & & Damming the Mekong webinar $(9 / 20)$ \\
\hline$S C$ researcher commentary $(1 / 21)$ & & CICP Mekong Conference $(10 / 20)$ \\
\hline 1st MDM announcement $(1 / 21)$ & & China-India Politics webinar $(11 / 20)$ \\
\hline 2nd MDM announcement $(1 / 21)$ & & CICP webinar on ASEAN $(1 / 21)$ \\
\hline 3rd MDM announcement $(2 / 21)$ & & UNECE webinar on Data sharing $(2 / 21)$ \\
\hline EJN-EWC-SC grant for journalists $(2 / 21)$ & & Mekong Delta conference $(3 / 21)$ \\
\hline 4th MDM announcement $(3 / 21)$ & & CICP US-China relations webinar $(3 / 21)$ \\
\hline 5th MDM announcement $(3 / 21)$ & & EWC Dialogue (4/21) \\
\hline 6th MDM announcement $(3 / 21)$ & & SUMERNET grant for journalists $(4 / 21)$ \\
\hline 7th MDM announcement $(4 / 21)$ & & CICP US-China webinar $(5 / 21)$ \\
\hline MDM announced biases in datasets $(4 / 21)$ & & CU-SEVANA commentary $(5 / 21)$ \\
\hline 1st MDM informal online meeting $(4 / 21)$ & & 1st ASEAN-MRC Dialogue $(8 / 21)$ \\
\hline 8th MDM announcement $(4 / 21)$ & & CU-CDRI water diplomacy report $(8 / 21)$ \\
\hline 9 th MDM announcement $(4 / 21)$ & & CSIS US-Laos Partnership webinar $(9 / 21)$ \\
\hline
\end{tabular}

SC and CTU commentary $(5 / 21)$

2nd MDM informal online meeting $(5 / 21)$

10th MDM announcement (5/21)

11th MDM announcement $(5 / 21)$

12th MDM announcement $(5 / 21)$

13th MDM announcement $(5 / 21)$

14th MDM announcement (5/21)

15th MDM announcement (5/21)

16th MDM announcement (5/21)

3rd MDM informal online meeting $(6 / 21)$

SC researcher webinar $(6 / 21)$

EoE Improvement report $(6 / 21)$

MDM announced a major update $(7 / 21)$

17 th MDM announcement $(7 / 21)$

18th MDM announcement $(7 / 21)$

19th MDM announcement (7/21)

MDM virtual workshop $(8 / 21)$

20th MDM announcement (9/21)

* Abbreviations: Stimson Center (SC), Eyes on Earth (EoE), Mekong Dam Monitor (MDM), Environmental Journalist Network (EJN), East-West Center (EWC), CTU (Can Tho University), Lancang-Mekong Water Cooperation and Information Platform (LMWCIP), Mekong River Commission (MRC), Australia-Mekong Partnership for Environmental Resources \& Energy Systems (AMPERES), Foreign Correspondents' Club of Thailand (FCCT), Chulalongkorn University (CU), Cambodia Institute for Cooperation and Peace (CICP), Cambodia Development Resource Institute (CDRI), Center for Strategic \& International Studies (CSIS). 
By reviewing the Chinese research feedback, we found that Chinese researchers rarely shared their scientific viewpoints on the Chinese mainstream dams through official or public media [200-202]. Nevertheless, one particular research study raised attention for indirectly refuting the EoE Study conclusions and highlighting the positive effects of the Chinese mainstream dams on the river [66]. Although there is still no research consensus over this water narrative, there can be found a vast number of research studies filling the gaps in upstream environmental cumulative impacts and other water-related challenges [88,203-206]. Surprisingly, despite the EoE Study opponents often marginalizing the Chinese researchers, the critical research viewpoints from the international community are being overlooked, too [26]. Perhaps the most important role in depoliticizing the Chinese mainstream dams is that played by the MRC, which is responsible for providing high-quality research assessments and other water-related notifications [207]. Moreover, unlike the research institutions operating within and outside of the basin to facilitate the accountable research dialogue, the MRC has experienced numerous political pressures and various retaliatory actions from multi-stakeholders for not accommodating a more critical attitude toward the hydropower development [90,208-210]. However, since several US policy-makers and other US researchers started using various research platforms as a political tool to justify the anti-dam narratives [162,165,185,211], the Lancang-Mekong water science dialogue has slowly become an arena of contradictory water narratives.

\subsubsection{Media Inputs}

The last analyzed group stimulating the debate about the Chinese mainstream dams can be found in terms of civil society and other individuals developing their ideas in public media. As is shown in Table 5, we divided the inputs according to the source, date and shared content to better illustrate the general trends in the politicization of hydropower development. Whereas both Chinese and foreign media were very active in interpreting the positive and negative features of the hydropower development, the downstream media texts were predominantly driven by Thai and Vietnamese media. Surprisingly, unlike the EoE Study, which mainly resonated in the official and research channels, most of the public media quoted the Stimson Center commentary, which already developed the EoE Study findings beyond data and put the EoE Study conclusions into a broader political context $[26,27,186]$. This trend has also been followed by connecting hydropower development with non-water- and non-basin-related issues [71,90,91]. Perhaps the most significant attention was paid to justifying or refuting the EoE Study conclusions as well as demoting the LMWCIP-MDM performance. Popular topics included, among others, reflecting the unregulated hydropower development and highlighting numerous solutions inquiring into systemic political reforms and the mutual willingness of political representatives. However, similar to the limited policy-research inputs, the downstream media rarely brought new topics and more often commented on already written articles published by foreign media. On the other hand, the downstream public media were more determined to find feasible solutions for ensuring their water security regardless of the source of the hydro-meteorological changes and more often put the hydrological changes into the broader socio-cultural context. Surprisingly, despite the public resentment and socially constructed hope to significantly mitigate the hydro-meteorological changes, no mass protests, letters of concern or filled lawsuits on account of Chinese mainstream dams have followed the publication of the EoE Study. 
Table 5. List of civil society and other inputs discussing the Chinese mainstream dams*.

\begin{tabular}{|c|c|c|}
\hline Source & Period & Content \\
\hline $\begin{array}{ll}\text { Chinese media } \\
\text { - } \quad \text { Global Times } \\
\text { - } \quad \text { SCMP } \\
\text { - } \quad \text { China Daily } \\
\text { - } \quad \text { CGTN } \\
\text { - } \quad \text { Xinhua } \\
\text { - } \quad \text { Other } \\
\text { Foreign media } \\
\text { - } \quad \text { The Diplomat } \\
\text { - } \quad \text { VoA News } \\
\text { - } \quad \text { Reuters } \\
\text { - } \quad \text { The Third Pole } \\
\text { - } \quad \text { Other } \\
\text { Downstream media } \\
\text { - } \quad \text { Bangkok Post } \\
\text { - } \quad \text { Benar News } \\
\text { - } \quad \text { Vietnam Times } \\
\text { - } \quad \text { Other }\end{array}$ & 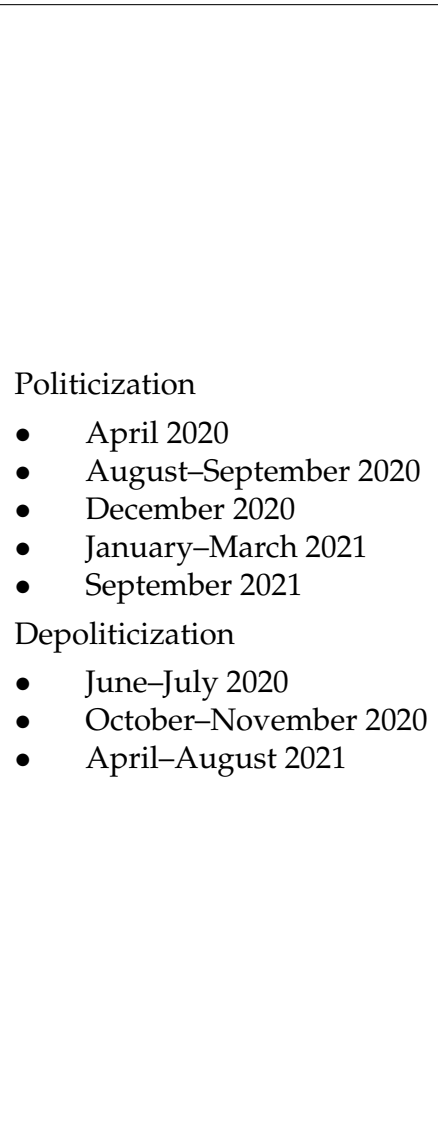 & $\begin{array}{l}\text { Chinese media } \\
\text { - } \quad \text { Accuracy, biases and funding of the EoE Study } \\
\text { - } \quad \text { Politicization of water science and Chinese dams } \\
\text { - } \quad \text { LMC and MUP geopolitics } \\
\text { - } \quad \text { Tsinghua University Study } \\
\text { - } \quad \text { MDM agenda, technical capacities and mandate } \\
\text { - } \quad \text { Impact of the COVID-19 on conflict resolution } \\
\text { - } \quad \text { LMC benefits for downstream countries } \\
\text { Foreign media } \\
\text { - } \quad \text { Irrefutability of the EoE Study findings } \\
\text { - } \quad \text { Sustainability of the water flow and Chinese dams } \\
\text { - } \quad \text { Mutual trust and collective actions } \\
\text { - } \quad \text { LMC and MUP geopolitics } \\
\text { - } \quad \text { MDM agenda, technical capacities and mandate } \\
\text { - } \quad \text { Impact of dams on water quality and quantity } \\
\text { - } \quad \text { MDM benefits for downstream countries } \\
\text { - } \quad \text { Other } \\
\text { Downstream media } \\
\text { - } \quad \text { Advancing adaptation strategies based on historical records } \\
\text { - } \quad \text { Simplification and misinterpretation of water science } \\
\text { - } \quad \text { Solutions for deteriorating the water quantity and quality } \\
\text { - } \quad \text { Better and timely notification about sudden water changes } \\
\text { - } \quad \text { Civil society engagement in the decision-making process } \\
\text { - } \quad \text { Co-development knowledge and promoting citizen science } \\
\text { - } \quad \text { Other }\end{array}$ \\
\hline
\end{tabular}

* Indicates general inclination and unique traits in each media discourse.

By drawing on the time period of politicization and depoliticization of the Chinese mainstream dams, the highest number of media inputs arose right after the publication of the EoE Study in April 2020 [25] and before the establishment of the MUP in AugustSeptember 2020 [170], when the US policy-makers re-considered their involvement in Southeast Asia. Another milestone belongs to January-March 2021, when downstream countries faced prolonged severe droughts and experienced information shortage about the upstream water operations [174-176]. The decline of media inputs can be predominantly found during the wet seasons, when downstream countries enjoy relative water abundance. However, by comparing the media inputs with MDM Facebook and Twitter social media accounts, we found some extra content beyond the MDM official websites. Such additional content included raising speculations about the Lancang tributary dams and the potential impact of upstream dams on the flooding of migratory bird nests, as well as justifying the biases in existing datasets that do not affect the EoE Study conclusions [26]. Nevertheless, apart from "verifying" the MDM datasets according to several correspondents living in downstream countries and sharing the content that highlights the MDM positive performance [27], the most significant trait of the MDM social media content presents the over-use of the internet hashtags, simplified language and mixing the official content with the personal viewpoints of the administrators. While such change in communication may positively raise public awareness about the Lancang-Mekong hydrological changes and encourage more multi-stakeholders to provide their insight into current water challenges, the mismatch in the MDM content and lowering the communication standards often lead to the discussion without data, which subsequently downgrades the quality of MDM social media content. 


\section{Discussion}

\subsection{Power of Symbolism}

To date, hydropower development has a very symbolic role in multiplying benefits and deepening water challenges amplified by various hydro-meteorological aspects. Because the majority of the multi-stakeholders call for improving the accuracy of the predictive hydrological models and better transparency of the hydrological data, there are certain aspects that should be furtherly elaborated. As we mentioned above, there is a huge perception asymmetry among multi-stakeholders. For policy-makers, the hydropower dams present a political tool facilitating their agenda and enlarging the pie of multifarious benefits among multi-stakeholders. When the actual benefits outweigh the negatives, the policy-makers are more prone to negotiate about sustainable hydropower development and re-consider the priorities in the public domain. While the tipping point for such behavioral change was historically triggered by the sudden hydro-meteorological changes $[26,84,85]$, the long-term lack of hydrological data about upstream water operation and China's limited engagement in the transboundary water governance contributed to mutual distrust and numerous communication biases. Within the last two decades, media attention was paid to the mainstream hydropower dams, particularly those in China, where most of these water projects are located. After a series of comprehensive hydrological studies studying the complex implications of the mainstream dams on the river [11-13], many observers identified upstream policy-makers and various business companies as a source of the problem $[21,71]$. Although the criticism of China's water policy approach ranged from an unwillingness to become a full member of the MRC [37,142,212], late notifications and scarce consultations [87,99] to limited willingness to share more hydrological data [42], the main motivation of sharing hydrological data between upstream and downstream governments was driven by the principle of reciprocity [105] and China's willingness to keep good neighbourhood relations $[39,53,68]$. Yet, despite the fact that China's government started to share the upstream hydrological data from the LMWCIP in November 2020 [31], what incentives for China's government are there for paying extra costs and providing more detailed hydrological data if these data seem not to be operationalized by the downstream governments or by the other multi-stakeholders?

\subsection{Complaints over Solutions}

Downstream countries are not powerless $[37,213]$ and possess enough capacity to regulate the basin development [20,22,137-139], which means that the degree of shared hydrological data does not present a problem. The real problem presents insufficient engagement of the downstream multi-stakeholders into the transboundary joint management and a lack of a positive mindset ensuring sustainable hydropower development. After April 2020, when the EoE Study and Stimson Center commentary re-politicized the Chinese mainstream dams [24,173], the dialogue over the actual impact of hydropower dams moved from the "problem-solution" to the "problem-victim" narrative [26]. While the main motivation for the US scientists along with the Eyes on Earth was to fill the information gaps and better understand amplifying effects of Chinese mainstream dams on the river, developing the arguments through public media and other non-traditional research channels provided very shallow high-quality research output. In addition, since the MDM does not include the researchers from the riparian states, does not use Chinese upstream hydrological data or consult their datasets with the LMWCIP [199], joining the US bandwagon for replicating the US knowledge, and getting other benefits from transferring the responsibility for transboundary water governance to the US government can be troublesome. Nevertheless, despite the fact that MDM efforts have been mainly oriented to facilitating the publicscience dialogue and improving the MDM datasets to compensate the limited downstream state official's inputs, there is a lot of space for improvement in depoliticizing water science, particularly in terms of the LMWCIP. So far, most of China's water notifications have been provided either the day after the sudden changes or 6 days rather than 14 days in advance, as was requested from the downstream countries and foreign donors [175,211]. Other 
potential progress can be identified in terms of synchronizing different methodologies and addressing the data inconsistencies $[174,214]$ to speed up the early warning system for the downstream countries. Moreover, because providing more detailed hydrological data is not cheap, combining the satellite images with standard hydrological procedures may positively reduce the actual cost and stimulate further research acknowledging the cumulative environmental impacts, particularly in terms of climate change, tributary dams and agricultural modernization.

\section{Conclusions}

To conclude, whenever the hydropower dams are interpreted as good or bad, feasible solutions to overcome the existing challenges within the Lancang-Mekong Basin are a shared priority among all multi-stakeholders. Moreover, despite the fact that upstream mainstream dams are widely considered a renewable source of energy with negligible economic benefits and high socio-environmental costs for the downstream countries $[16,17,21,71,91]$, abandoning or decommissioning hydropower dams is not a viable option. Instead, multi-stakeholders should deeply re-consider what they want and what they need before levelling their demands from upstream countries. Within more than two decades, Chinese mainstream dams have attracted significant media attention. Yet, apart from sharing misinformation on social media $[137,138]$ and devaluating the Chinese actions beyond the water context [24,29], many multi-stakeholders can legitimize their interests and deny other viewpoints that do not fit their prior beliefs [26,27]. Although every multi-stakeholder has a right to their own opinion, refuting the "undesirable" water narratives without robust evidence and wide research consensus can unnecessarily prolong the conflict of ideas and cement the harmful stereotypes. Since the Eyes on Earth and the MDM have no authority or operational hydrological data upon which one could determine the actual impact of Chinese mainstream dams, further consultation with the LMWCIP and MRC will be required to synchronize the research outputs and coordinate the future development pathways for the sustainable hydropower sector. Moreover, by narrowing the research dialogue, ostracizing the undesirable research viewpoints and alienating water science through the public and social media, more systemic effort needs to be made by providing high-quality research inputs, regulating the overstatements on the official websites and improving the engagement of the downstream multi-stakeholders in the transboundary water management.

Author Contributions: R.G. designed and supervised the research; W.W. participated in data collection and data verification and contributed to the writing of the paper; Y.F. provided supervision during the original draft preparation and helped during the project administration. All authors have read and agreed to the published version of the manuscript.

Funding: This research was funded by the Yunnan Basic Research Program (grant number 202101AT070185) and the Natural Science Foundation of China (grant number 41701626).

Institutional Review Board Statement: Not applicable.

Informed Consent Statement: Not applicable.

Data Availability Statement: Not applicable.

Acknowledgments: The authors thank the editor and three peer reviewers for valuable comments improving the quality of the presented research. We would also like to thank Yunnan University for administrative support during the investigations and Carl Lark for his positive mindset during the coronavirus pandemic.

Conflicts of Interest: The authors declare no conflict of interest.

\section{References}

1. Bakker, K. The politics of hydropower: Developing Mekong. Political Geogr. 1999, 18, 209-232. [CrossRef]

2. Wolf, A.T.; Yoffe, S.B.; Giordano, M. International Waters: Identifying basin at risk. Water Policy 2003, 5, 29-60. [CrossRef] 
3. Hewison, K. Bankers and Bureaucrats: Capital and the Role of the State in Thailand; Yale University of South East Asia Studies: New Haven, CT, USA, 1989.

4. Hori, H. The Mekong: Environment and Development; United Nations University Press: Tokyo, Japan, 2000.

5. Glassman, J. Interpreting the economic crisis in Thailand: Lessons learned and lessons obscured. In Radicalising Thailand: New Political Perspectives; Ungaporn, J.G., Ed.; Chulalongkorn University: Bangkok, Thailand, 2003; pp. 75-119.

6. Hensengerth, O. Regionalism in China-Vietnam Relations. Institution-Building in the Greater Mekong Subregion; Routledge: Oxon, UK, 2010.

7. Brady, C. Southeast Asia: The Mekong River. In Resource Politics: Freshwater and Regional Relations; Thomas, C., Howlett, D., Eds.; Open University Press: Buckingham, UK, 1993; pp. 86-109.

8. Stewart, M.A.; Coclanis, P.A. Water and Power. Environmental Governance and Strategies for Sustainable in the Lower Mekong Basin; Springer: Cham, Switzerland, 2019.

9. Sneddon, C. Water, governance and hegemony. In Contemporary Water Governance in the Global South: Scarcity, Marketization and Participation; Harris, L., Goldin, J., Sneddon, C., Eds.; Routledge: New York, NY, USA, 2013; pp. 13-24.

10. Sneddon, C.; Fox, C. Power, development and institutional change. Participatory governance in the Lower Mekong basin. World Dev. 2008, 35, 2161-2181. [CrossRef]

11. Mekong River Commission. The Council Study. The Study on the Sustainable Management and Development of the Mekong River Basin Including Impacts of Mainstream Hydropower Projects; Mekong River Commission Secretariat: Vientiane, Laos, 2017.

12. International Center for Environmental Management. MRC Strategic Environment Assessment (SEA) of Hydropower on the Mekong Mainstream; Final Report; Mekong River Commission: Hanoi, Vietnam, 2010.

13. Mekong River Commission. Modelling the Cumulative Barrier and Passage Effects of Mainstream Hydropower Dams on Migratory Fish Populations in the Lower Mekong Basin: Meeting the Needs, Keeping the Balance; Mekong River Commission Secretariat: Vientiane, Laos, 2009.

14. Binh, D.V.; Kantoush, S.A.; Saber, M.; Mai, N.P.; Maskey, S.; Phong, D.T.; Sumi, T. Long-term alternations of flow regimes of the Mekong River and adaptation strategies for the Vietnamese Mekong Delta. J. Hydrogeol. Reg. Stud. 2020, 32, 100742.

15. Hirsch, P. The shifting regional geopolitics of Mekong dams. Political Geogr. 2016, 51, 53-74. [CrossRef]

16. Biba, S. China's Continuous Dam-building on the Mekong River. J. Contemp. Asia 2012, 42, 603-628. [CrossRef]

17. Biba, S. From securitization moves to positive outcomes: The case of the spring 2010 Mekong crisis. Secur. Dialogue 2016, 47 , 420-439. [CrossRef]

18. Gunn, G.; McCartan, B. Chinese Dams and the Great Mekong Floods of 2008. Asia Pac. J. 2008, 6, 1-6.

19. Kummu, M.; Varis, O. Sediment-related impacts due to upstream reservoir trapping, the Lower Mekong River. Geomorphology 2007, 85, 275-293. [CrossRef]

20. Baird, I.G.; Silvano, R.A.M.; Parlee, B.; Poesch, M.; Maclean, B.; Napoleon, A.; Lepine, M.; Hallwass, G. The Downstream Impacts of hydropower Dams and Indigenous and Local Knowledge: Examples from the Peace-Athabasca, Mekong, and Amazon. Environ. Manag. 2021, 67, 682-696. [CrossRef]

21. Matthews, N.; Geheb, K. Hydropower Development in the Mekong Region: Political, Socio-Economic and Environmental Perspectives; Routledge: New York, NY, USA, 2015.

22. Mirumachi, N. Transboundary Water Politics in the Developing World; Routledge: New York, NY, USA, 2015.

23. Hafner, A. Negotiating for Water Resources. Bridging Transboundary River Basins; Earthscan: New York, NY, USA, 2016.

24. Basist, A.; Williams, C. Monitoring the Quantity of Water Flowing through the Upper Mekong Basin Under Natural (Unimpeded) Conditions; Sustainable Infrastructure Partnership: Bangkok, Thailand, 2020.

25. Grünwald, R.; Feng, Y.; Wang, W. Politicization of science in the Lancang-Mekong Basin: The Eyes on Earth Study. Int. J. Water Resour. Dev. 2021, 1-27. [CrossRef]

26. Grünwald, R. Lancang-Mekong Cooperation: Overcoming the Trust Deficit on the Mekong. ISEAS 2021, 89, 1-16.

27. Ketelsen, T.; Sawdon, J.; Räsärenen, T. Monitoring the Quantity of Water Flowing through the Upper Mekong Basin under Natural (Unimpeded) Conditions; Rapid Review; AMPERES: Perth, Australia, 2020.

28. Kallio, M.; Fallon, A. Are China's Dams on the Mekong Causing Downstream Drought? The Importance of Scientific Debate; Faculty of Political Science at Chulalongkorn University: Bangkok, Thailand, 2020.

29. Keovilignavong, O.; Nguyen, T.H.; Hirsch, P. Reviewing the causes of Mekong drought before and during 2019-20. Int. J. Water Resour. Dev. 2021, 1-21. [CrossRef]

30. Mekong River Commission. Understanding the Mekong River's Hydrological Conditions: A Brief Commentary Note on the "Monitoring the Quantity of Water Flowing through the Upper Mekong Basin under Natural (Unimpeded) Conditions" Study by Alan Basist and Claude Williams (2020); Mekong River Commission Secretariat: Vientiane, Laos, 2020.

31. Ministry of Foreign Affairs of the People's Republic of China. Available online: https://www.fmprc.gov.cn/eng/wjb_663304 /zzjg_663340/yzs_663350/xwlb_663352/202012/t20201203_508916.html (accessed on 31 December 2021).

32. Stimson Center. Available online: https://www.stimson.org/event/launch_of_the_mekong_dam_monitor/ (accessed on 31 December 2021).

33. Molle, F.; Mollinga, P.P.; Wester, P. Hydraulic Bureaucracies and the Hydraulic Mission: Flows of Water, Flows of Power. Water Altern. 2009, 3, 328-349. 
34. Menga, F.; Mirumachi, N. Fostering Tajik Hydraulic Development: Examining the Role of Soft Power in the Case of the Rogun Dam. Water Altern. 2016, 9, 373-388.

35. Menga, F. Building a nation through a dam: The case of Rogun in Tajikistan. Natl. Pap. 2015, 43, 479-494. [CrossRef]

36. Sneddon, C.; Fox, C. Rethinking transboundary waters: A critical hydropolitics of the Mekong basin. Political Geogr. 2006, 25, 181-202. [CrossRef]

37. Backer, E.B. The Mekong River Commission: Does it Work, and How Does the Mekong Basin's Geography Influence Its Effectiveness? J. Curr. Southeast Asian Aff. 2007, 26, 32-56.

38. Mayeda, A.M.; Boyd, A.D. Factors influencing public perceptions of hydropower projects: A systematic literature review. Renew. Sustain. Energy Rev. 2020, 121, 1-21. [CrossRef]

39. Grünwald, R. Role of the Water Security in the International Relations: The Mekong River Basin Case Study. Ph.D. Thesis, Metropolitan University of Prague, Prague, Czech Republic, 4 July 2018.

40. Thu, H.N.; Wehn, U. Data sharing in international transboundary context: The Vietnamese perspective on data sharing in the Lower Mekong Basin. J. Hydrol. 2016, 536, 351-364. [CrossRef]

41. Cronin, R.P.; Hamlin, T. Mekong Tipping Point: Hydropower Dams, Human Security and Regional Stability; The Henry L. Stimson Center: Washington, DC, USA, 2010.

42. Gleick, P.H. Water and Conflict: Freshwater Resources and International Security. Int. Secur. 1993, 18, 79-112. [CrossRef]

43. Null, S.E.; Farshid, A.; Goodrum, G.; Gray, C.A.; Lohani, S.; Morrisett, C.N.; Prudencio, L.; Sor, R. Meta-Analysis of Environmental Tradeoffs of Hydropower Dams in the Sekong, Sesan, and Srepok (3S) Rivers of the Lower Mekong Basin. Water 2020, 13, 63. [CrossRef]

44. Molle, F.; Foran, T.; Käkonen, M. Contested Waterscapes in the Mekong Region: Hydropower, Livelihoods and Governance; Earthscan: London, UK, 2009.

45. Wyatt, A.B.; Baird, I.G. Transboundary Impact Assessment in the Sesan River Basin: The Case of the Yali Falls Dam. Int. J. Water Resour. Dev. 2007, 23, 427-442. [CrossRef]

46. World Commission on Dams. Pak Mun Dam-Mekong River Basin, Thailand; Secretariat of the World Commission on Dams: Cape Town, South Africa, 2000.

47. Jenkins, D. The Lower Mekong Scheme. Asia Surv. 1968, 8, 456-464. [CrossRef]

48. Wolf, E. Ownership and Political Ecology. Anthropol. Q. 1972, 45, 201-205. [CrossRef]

49. Enzensberger, H. A critique of political ecology. New Left Rev. 1974, 84, 3-31.

50. Watts, M.; Peet, R. (Eds.) Liberating Political Ecology. In Liberation Ecologies: Environment, Development, Social Movements; Routledge: London, UK, 2004.

51. Cronon, W. Uncommon Ground: Toward Reinventing Nature; Norton: New York, NY, USA, 1996.

52. Leach, M.; Mearns, R. The Lie of the Land: Challenging Received Wisdom on the African Environment; James Currey: Oxford, UK, 1996.

53. Grünwald, R.; Andělová, P. Hydroillusion: Transboundary Water Disputes from Point of View of Critical Political Ecology; Metropolitan University of Prague Press: Prague, Czech Republic, 2016.

54. Peet, R.; Robbins, P.; Watts, M. Global Political Ecology; Routledge: London, UK, 2011.

55. Scott, P.A.; Sullivan, S. Political Ecology: Science, Myth and Power; Routledge: London, UK, 2000.

56. Bassett, T.J.; Zimmerer, K.S. Cultural ecology. In Geography in America at the Dawn of the Twenty-First Century; Gaile, G., Willmott, C., Eds.; Oxford University Press: Oxford, UK, 2004.

57. Perreault, T.; Bridge, G.; McCarthy, J. The Routledge Handbook of Political Ecology; Routledge: London, UK, 2015.

58. Walker, P.A. Political ecology: Where is the politics? Prog. Hum. Geogr. 2007, 29, 363-369. [CrossRef]

59. Forsyth, T. Critical Political Ecology: The Politics of Environmental Science; Routledge: New York, NY, USA, 2003.

60. Khan, T.H.; MacEachen, E. Foucaldian Discourse Analysis: Moving Beyond a Social Constructivist Analytic. Int. J. Qual. Methods 2021, 20, 16094069211018009. [CrossRef]

61. Derrida, J. Of Grammatology; Johns Hopkins University Press: Baltimore, MD, USA, 1997.

62. Gleditsch, N.P.; Furlong, K.; Hegre, H.; Lacina, B.; Owen, T. Conflicts over shared rivers: Resource scarcity or fuzzy boundaries? Political Geogr. 2006, 25, 361-382. [CrossRef]

63. Bakker, M. Transboundary river floods: Examining countries, international river basins and continents. Water Policy 2009, 11, 269-288. [CrossRef]

64. De Soysa, I. Paradise is a Bazaar? Greed, Creed, and Governance in Civil War, 1989-1999. J. Peace Res. 2002, 39, 395-416. [CrossRef]

65. Zeitoun, M.; Cascão, A.; Warner, J.; Mirumachi, N.; Matthews, N.; Menga, F.; Farnum, R. Transboundary water interaction III: Contest and compliance. Int. Environ. Agreem. Politics Law Econ. 2017, 17, 271-294. [CrossRef]

66. Wegerich, K.; Warner, J.F. The Politics of Water: A Survey; Routledge: New York, NY, USA, 2010.

67. Jägerskog, A. The power of the "sanctioned discourse"-A crucial factor in determining water policy. Water Policy 2003, 47, 161-166. [CrossRef]

68. Conker, A. An Enhanced Notion of Power for Inter-State and Transnational Hydropolitics: An Analysis of Turkish-Syrian Water Relations and the Ilısu Dam Conflict between the Opponents and Proponents of the Dam. Ph.D. Thesis, University of East Anglia, East Anglia, UK, June 2014.

69. Zeitoun, M.; Warner, J.F. Hydro-hegemony-A Framework for analysis of trans-boundary water conflicts. Water Policy 2006, 8 , 435-460. [CrossRef] 
70. Gleick, P.H. Water and terrorism. Water Policy 2006, 8, 481-503. [CrossRef]

71. Motta, S.; Matthews, N. Rewards and risks of Chinese hydropower in the Mekong River Basin (GMS). In Chinese Hydropower Development in Africa and Asia. Challenges and Opportunities for Sustainable Global Dam-Building; Siciliano, G., Urban, F., Eds.; Routledge: New York, NY, USA, 2017.

72. Warner, J.; Zawahri, N. Hegemony and asymmetry: Multiple-chessboard games on transboundary rivers. Int. Environ. Agreem. Policies Law Econ. 2012, 12, 215-229. [CrossRef]

73. Gleick, P.; Heberger, M.; Donnelly, K. Zombie Water Projects. In The World's Water; Gleick, P.H., Ed.; Island Press: Washington, DC, USA, 2014; pp. 123-146.

74. Chheang, V. Lancang-Mekong Cooperation: A Cambodian Perspective. ISEAS 2018, 70, 1-9.

75. Cuttita, P. Repoliticization through Search and Rescue? Humanitarian NGOs and Migration Management in the Mediterranean. Geopolitics 2018, 23, 632-660. [CrossRef]

76. Atkins, E. Disputing the 'National Interest': The Depoliticization and Repoliticization of the Belo Monte Dam, Brazil. Water 2019, 11, 103. [CrossRef]

77. Jessop, B. Repoliticising depoliticization: Theoretical preliminaries on some responses to the American fiscal and Eurozone debt crises. Policy Politics 2014, 42, 207-223. [CrossRef]

78. Albrecht, F. Natural hazards as political events: Framing and politicization of floods in the United Kingdom. Environ. Hazards 2021, 1-19. [CrossRef]

79. Eden, S. Public participation in environmental policy: Considering scientific, counter-scientific and non-scientific. Public Underst. Sci. 1996, 5, 183-204. [CrossRef]

80. Beck, U. Risk Society: Towards a New Modernity; Sage: London, UK, 1992.

81. Savenije, H.H.G.; Hoekstra, A.Y.; Van der Zaag, P. Evolving Water Science in the Anthropocene. Hydrol. Earth Syst. Sci. 2014, 18, 319-332. [CrossRef]

82. Baron, N. A Guide to Making Your Science Matter. Escape from the Ivory Tower; Island Press: Washington, DC, USA, 2010.

83. Bouleau, G. Politicization of Ecological Issues. From Environmental Forms to Environmental Motives; ISTE: London, UK, 2019.

84. Campbell, I.C. Development Scenarios and Mekong River Flows. In The Mekong-Biophysical Environment of an International River Basin; Champbell, I.C., Ed.; Elsevier Press: Burlington, UK, 2009; pp. 389-402.

85. Campbell, I.C.; Manusthirapom, C. Technical Report on Rainfall and Discharge in the Lower Mekong Basin in 2003-2004; Mekong River Commission Secretariat: Vientiane, Laos, 2009.

86. Mekong River Commission. Flood Situation Report, August 2008; Technical Paper, No. 21; Mekong River Commission Secretariat: Vientiane, Laos, 2008.

87. Mekong River Commission. Hydrological Conditions in the Lower Mekong River Basin in January-July 2020; Mekong River Commission Secretariat: Vientiane, Laos, 2020.

88. Tian, F.; Liu, H.; Hou, S.; Li, K.; Lu, H.; Ni, G.; Mu, X.; Bai, Y. Drought Characteristics of Lancang-Mekong River Basin and the Impacts of Reservoir Regulation on Streamflow; Tsinghua University: Beijing, China, 2020.

89. Zhang, H. Sino-Indian water disputes: The coming water wars? WIREs Water 2016, 3, 155-166. [CrossRef]

90. Grünwald, R. Lancang Mekong Cooperation: Present and Future of the Mekong River Basin. J. Political Sci. 2020, $23,69-97$. [CrossRef]

91. Siciliano, G.; Urban, F.; Tan-Mullins, M.; Pichdara, L.; Kim, S. The Political Ecology of Chinese Large Hydropower Dams in Cambodia: Implications, Challenges and Lessons Learnt from the Kamchay Dam. Water 2016, 8, 405. [CrossRef]

92. Zwahlen, R. (Ed.) Mekong Basin. In Assessing the Environmental Impacts of Hydropower Projects; Springer: Cham, Switzerland, 2022; pp. 489-512.

93. Ministry of Foreign Affairs of the People's Republic of China. Available online: https://www.fmprc.gov.cn/mfa_eng/wjdt_6653 85/2649_665393/201603/t20160323_679441.html (accessed on 31 December 2021).

94. Mekong River Commission. Available online: http://www.mrcmekong.org/news-and-events/news/chinas-emergency-watersupply-increased-mekongs-water-level-says-an-mrc-china-joint-study / (accessed on 31 December 2021).

95. Mekong River Commission. Available online: http://www.mrcmekong.org/news-and-events/news/mrc-secretariat-lmc-watercenter-ink-first-mou-for-better-upper-lower-mekong-management/ (accessed on 31 December 2021).

96. Ministry of Water Resources of People's Republic of China. Available online: http:/ /www.mwr.gov.cn/english/Medianews/20 2112/t20211220_1556112.html (accessed on 31 December 2021).

97. Mekong River Commission. Minutes of Twenty-Fourth Dialogue Meeting of the MRC Joint Committee; Mekong River Commission Secretariat: Vientiane, Laos, 2020.

98. Sumernet. Available online: https://www.sumernet.org/story/lancang-mekong-research-and-policy-forums-on-27-28-oct (accessed on 31 December 2021).

99. Mekong River Commission. Hydrological Impacts of the Lancang Hydropower Cascade on Downstream Extreme Events; Mekong River Commission Secretariat: Vientiane, Laos, 2019.

100. Venus, T.E.; Hinzmann, M.; Bakken, T.H.; Gerdes, H.; Godinho, F.N.; Hansen, B.; Pinheiro, A.; Sauer, J. The public's perception of run-of-the-river hydropower across Europe. Energy Policy 2020, 140, 111422. [CrossRef]

101. Yang, R.R. The leading role of Yunnan hydropower in national "West to East Electricity Transmission Strategy". Yunnan Water Power 2001, 17, 1-5. 
102. Daojiong, Z. Hydropower development in China. In Hydropower Development in the Mekong Region: Political, Socio-Economic and Environmental Perspectives; Matthews, N., Geheb, K., Eds.; Routledge: New York, NY, USA, 2015; pp. 32-82.

103. Santalco, A. How and when China will exceed its renewable energy deployment targets. Energy Policy 2012, 51, 653-661. [CrossRef]

104. Boelens, R.; Getches, D.; Guevaragil, A. Out of the Mainstream. Water Rights, Politics and Identity; Earthscan: London, UK, 2010.

105. Zhong, Y.; Tian, F.; Hu, H.; Grey, D.; Gilmont, M. Rivers and reciprocity: Perceptions and policy on international watercourses. Water Policy 2016, 18, 803-825. [CrossRef]

106. Jiménez, A.; Saikia, P.; Giné, R.; Avello, P.; Leten, J.; Lymer, B.L.; Schneider, K.; Ward, R. Unpacking Water Governance: A Framework for Practitioners. Water 2020, 12, 827. [CrossRef]

107. Quark, A.A. Scientized politics and global governance in the cotton trade: Evaluating divergent theories of scientization. Rev. Int. Political Econ. 2012, 19, 895-917. [CrossRef]

108. Pardini, R.; Bertuol-Garcia, D.; Araújo, B.D.; Mesquita, J.P.; Murer, B.M.; Pônzio, M.C.; Ribeiro, F.S.; Rossi, M.L.; Prado, P.I. COVID-19 pandemic as a learning path for grounding conservation policies in science. Perspect. Ecol. Conserv. 2021, 19, 109-114. [CrossRef]

109. Wade, J. Duelling experts in mediation and negotiation: How to respond when eager expensive entrenched expert egos escalate enmity. Confl. Resolut. Q. 2004, 21, 419-436. [CrossRef]

110. Feng, Y.; Wang, W.; Suman, S.; Yu, S.; He, D. Water Cooperation Priorities in the Lancang-Mekong River Basin Based on Cooperative Events Since the Mekong River Commission Established. Chin. Geogr. Sci. 2019, 20, 58-69. [CrossRef]

111. Grünwald, R.; Feng, Y.; Wang, W. Reconceptualization of the Transboundary Water Interaction Nexus (TWINS): Approaches, opportunities and challenges. Water Int. 2020, 45, 458-478. [CrossRef]

112. Cascão, A.; Zeitoun, M. Power, hegemony and critical hydro-politics. In Trans-Boundary Water Management: Principles and Practice; Earle, A., Jagerskög, A., Öjendal, J., Eds.; Routledge: New York, NY, USA, 2010; pp. 27-42.

113. Fox, C.A.; Sneddon, C.S. Political Borders, Epistemological Boundaries, and Contested Knowledges: Constructing Dams and Narratives in the Mekong River Basin. Water 2019, 11, 413. [CrossRef]

114. Gerlak, A.K.; Schmeier, S. Climate Change and Transboundary Waters: A Study of Discourse in the Mekong River Commission. J. Environ. Dev. 2014, 23, 358-386. [CrossRef]

115. Wei, J.; Wei, Y.; Tian, F.; Nott, N.; De Witt, C.; Guo, L.; Lu, Y. News media coverage of conflict and cooperation dynamics of water events in the Lancang-Mekong River basin. Hydrol. Earth Syst. Sci. 2021, 25, 1603-1615. [CrossRef]

116. Ching, L. Social networks and perceptions of power in the Mekong. Water Altern. 2020, 13, 393-417.

117. Waitt, G. Doing Discourse Analysis. In Qualitative Research Methods in Human Geography; Hay, I., Ed.; Oxford University Press: London, UK, 2005; pp. 163-191.

118. Grünwald, R.; Wang, W.; Feng, Y. Modified Transboundary Water Interaction Nexus (TWINS): Xayaburi Dam Case Study. Water 2020, 12, 710. [CrossRef]

119. Evers, M.; Höllermann, B.; Almoradie, A.D.S.; Santos, G.G.; Taft, L. The Pluralistic Water Research Concept: A New Human-Water System Research Approach. Water 2017, 9, 933. [CrossRef]

120. Hamilton, S.H.; Fu, B.; Guillaume, J.H.A.; Badham, J.; Elsawah, S.; Gober, P.; Hunt, R.J.; Iwanaga, T.; Jakeman, A.J.; Ames, D.P.; et al. A framework for characterizing and evaluating the effectiveness of environmental modelling. Environ. Model. Softw. 2019, 118, 83-98. [CrossRef]

121. Han, P.; Mea, S.; An, H.P. Understanding Quality Energy-Related Infrastructure Development in the Mekong Subregion: Key Drivers and Policy Implications. ERIA Discuss. Pap. Ser. 2021, 363, 1-42.

122. Brochmann, M.; Hensel, P.R. The Effectiveness of Negotiations over International River Claims. Int. Stud. Q. 2011, 55, 859-882. [CrossRef]

123. Heikkila, T.; Gerlak, A.K.; Bell, A.; Schmeier, S. Adaptation in a transboundary river basin: Linking stressors and adaptive capacity within the Mekong River Commission. Environ. Sci. Policy 2013, 25, 73-82. [CrossRef]

124. Campbell, I.; Barlow, C. Hydropower Development and the Loss of Fisheries in the Mekong River Basin. Front. Environ. Sci. 2020, 8, 110. [CrossRef]

125. Lu, X.X.; Siew, R.Y. Water discharge and sediment flux changes in the Lower Mekong River. Hydrol. Earth Syst. Sci. 2005, 2, $2287-2325$

126. Fu, K.; He, D. Analysis and prediction of sediment trapping efficiencies of the reservoirs in the mainstream of the Lancang River Chin. Sci. Bull. 2007, 52, 134-140. [CrossRef]

127. Schultz, C.; Skinner, J. Hydropower benefit-sharing and resettlement: A conceptual review. Energy Res. Soc. Sci. $2022,83,102342$. [CrossRef]

128. Nguyen, H.T.; Pham, T.; Bruyn, L.L. Impact of Hydroelectric Dam Development and Resettlement on the Natural and Social Capital of Rural Livelihoods in Bo Hon Village in Central Vietnam. Sustainability 2017, 9, 1422. [CrossRef]

129. Meng, Y.; Liu, J.; Wang, Z.; Mao, G.; Wang, K.; Yang, H. Undermined co-benefits of hydropower and irrigation under climate change. Resour. Conserv. Recycl. 2021, 167, 105375. [CrossRef]

130. Zeng, R.; Cai, X.; Ringler, C.; Zhu, T. Hydropower versus irrigation-An analysis of global patterns. Environ. Res. Lett. 2017, 12, 034006. [CrossRef] 
131. Wang, W.; Lu, H.; Leung, L.R.; Li, H.Y.; Zhao, J.; Tian, F.; Yang, K.; Sothea, K. Dam Construction in Lancang-Mekong River Basin Could Mitigate Future Flood Risk From Warming-Induced Intensified Rainfall. Geophys. Res. Lett. 2017, 44, 10378-10386. [CrossRef]

132. Yasuda, Y. Rules, Norms and NGO Advocacy Strategies. Hydropower Development on the Mekong River; Routledge: Oxon, UK, 2015.

133. Stimson Center. Available online: https://www.stimson.org/2020/new-mekong-dam-monitor-brings-unprecedentedtransparency-to-base-wide-dam-operations / (accessed on 31 December 2021).

134. Ministry of Foreign Affairs of the People's Republic of China. Available online: https://www.fmprc.gov.cn/mfa_eng/wjb_6633 04/zzjg_663340/yzs_663350/gjlb_663354/2747_663498/2749_663502/202002/t20200222_519234.html (accessed on 31 December 2021).

135. Al Amin, M.A. Hydropower Resources as Target of Terrorism: Case Study of Selected Water Bodies in Northern Nigeria. Int. J. Eng. Sci. 2013, 11, 52-61.

136. Matthews, N. Water grabbing in the Mekong basin-An analysis of the winners and losers of Thailand's hydropower development in Lao PDR. Water Altern. 2012, 5, 392-411.

137. Siala, K.; Chowdhury, A.K.; Dang, T.D.; Galelli, S. Solar energy and regional coordination as a feasible alternative to large hydropower in Southeast Asia. Nat. Commun. 2021, 12, 4159. [CrossRef] [PubMed]

138. Vo, T.T.E.; Ko, H.; Huh, J.; Park, N. Overview of Possibilities of Solar Floating Photovoltaic Systems in the OffShore Industry Energies 2021, 14, 6988. [CrossRef]

139. Yeophantong, P. China and the Politics of Hydropower Development: Governing Water and Contesting Responsibilities in the Mekong River Basin; GEG Working Paper, No. 2013/81; University of Oxford, Global Economic Governance Programme (GEG): Oxford, UK, 2013.

140. Mekong River Commission. Available online: https://www.mrcmekong.org/news-and-events/op-ed/oped-improvingnavigation-channels-while-protecting-the-environment/ (accessed on 31 December 2021).

141. Lim, S. The Mekong Subregion's Growth Paradigm and Commitments to reduce inequalities. J. Greater Mekong Stud. 2020, 4, 17-30.

142. Kuenzer, C.; Campbell, I.; Roch, M.; Leinenkugel, P.; Tuan, V.T.; Dech, S. Understanding the impact of hydropower developments in the context of upstream-downstream relations in the Mekong river basin. Sustain. Sci. 2012, 8, 565-584. [CrossRef]

143. Kummu, M.; Sarkkula, A.J. Impact of the Mekong River flow alteration on the Tonle Sap flood pulse. AMBIO 2008, 37, 185-192. [CrossRef]

144. Mekong River Commission. Available online: https://www.facebook.com/mrcmekong/posts/4520804041275027 (accessed on 31 December 2021).

145. Mekong River Commission. Available online: http://www.mrcmekong.org/news-and-events/news/water-flow-from-chinasjinghong-station-to-fluctuate-but-no-major-impact-is-expected/ (accessed on 31 December 2021).

146. Tran, D.D.; Halsema, G.; Hellegers, P.J.G.J.; Hoang, L.P.; Ludwig, F. Long-term sustainability of the Vietnamese Mekong Delta in question: An economic assessment of water management alternatives. Agric. Water Manag. 2019, 223, 112. [CrossRef]

147. Hirsch, P. The changing political dynamics of dam building on the Mekong. Water Altern. 2010, 3, 312-323.

148. Phung, D.; Huy, T.N.; Tran, N.N.; Tran, D.N.; Doan, V.Q.; Nghiem, S.; Nguyen, N.H.; Nguyen, T.H.; Benneti, T. Hydropower dams, river drought and health effects: A detection and attribution study in the lower Mekong Delta Region. Clim. Risk Manag. 2021, 32, 100280. [CrossRef]

149. Soukhaphon, A.; Baird, I.G.; Hogan, Z.S. The Impacts of Hydropower Dams in the Mekong River Basin: A Review. Water 2021, 13, 265. [CrossRef]

150. Shi, W.; Chen, Q.; Zhang, J.; Chen, C.; Chen, Y.; Ji, Y.; Yu, J.; Van Dam, B. Spatial Patterns of Diffusive Methane Emissions across Sediment Deposited Riparian Zones in Hydropower Reservoirs. JGR Biogeosci. 2021, 126, e2020JG005945. [CrossRef]

151. Liu, H.; Yang, Z.; Xu, F.; Zhang, X.; Bai, Y.; Mu, X.; Hu, H. Drought in Lancang-Mekong River Basin and the impact of upstream reservoirs. J. China Inst. Water Resour. Hydropower Res. 2020, 18, 479-485.

152. Ziv, G.; Baran, E.; Nam, S.; Rodríguez-Iturbe, I.; Levin, S.A. Trading-off fish biodiversity, food security and hydropower in the Mekong River Basin. Proc. Natl. Acad. Sci. USA 2012, 109, 5609-5614. [CrossRef]

153. Baran, E.; Larinier, M.; Ziv, G.; Marmulla, G. Review of the Fish and Fisheries Aspects in the Feasibility Study and the Environmental Impact Assessment of the Proposed Xayaburi Dam on the Mekong Mainstream; WWF Greater Mekong: Bangkok, Thailand, 2011.

154. Bonnema, M.; Hossain, F.; Nijssen, B.; Holtgrieve, G. Hydropower's hidden transformation of rivers in the Mekong. Environ. Res. Lett. 2020, 15, 110. [CrossRef]

155. Zhang, Y.; Hao, Z.; Xu, C.Y.; Lai, X. Response of melt water and rainfall runoff to climate change and their roles in controlling streamflow changes of the two upstream basins over the Tibetan Plateau. Hydrol. Res. 2020, 51, 272-289. [CrossRef]

156. Trung, L.D.; Duc, N.A.; Nguyen, L.T.; Thai, T.H.; Khan, A.; Rautenstrauch, K.; Schmidt, C. Assessing cumulative impacts of the proposed Lower Mekong Basin hydropower cascade on the Mekong River floodplains and Delta-Overview of integrated modelling methods and results. J. Hydrol. 2018, 581, 122511. [CrossRef]

157. Lu, X.X.; Li, S.; Kummu, M.; Padawangi, R.; Wang, J.J. Observed changes in the water flow at Chiang Saen in the Lower Mekong: Impacts of Chinese dams? Quat. Int. 2014, 336, 145-157. [CrossRef]

158. Siciliano, G.; Urban, F.; Kim, S.; Lonn, P.D. Hydropower, social priorities and the rural-urban development divide: The case of large dams in Cambodia. Energy Policy 2015, 86, 73-285. [CrossRef] 
159. Embassy of the People's Republic of China in the Kingdom of Thailand. Available online: http:/ /www.chinaembassy.or.th/eng/ ztbd/t1384905.htm (accessed on 31 December 2021).

160. Embassy of the People's Republic of China in the Kingdom of Thailand. Available online: http:/ / www.chinaembassy.or.th/eng/ sgxw/t1678896.htm (accessed on 31 December 2021).

161. Silva, A.T.; Lucas, M.C.; Castro-Santos, T.; Katopodis, C.; Baumgartner, L.J.; Thiem, J.D.; Aarestrup, K.; Pompeu, P.S.; O’Brien, G.C.; Braun, D.C.; et al. The future of fish passage science, engineering, and practice. Fish Fish. 2017, 19, 340-362. [CrossRef]

162. U.S. Department of State. Available online: https://2017-2021.state.gov/special-briefing-with-david-r-stilwell-assistantsecretary-of-state-for-the-bureau-of-east-asian-and-pacific-affairs/index.html (accessed on 31 December 2021).

163. U.S. Department of State. Available online: https://2017-2021.state.gov/the-united-states-and-asean-are-partnering-to-defeatcovid-19-build-long-term-resilience-and-support-economic-recovery/index.html (accessed on 31 December 2021).

164. U.S. Department of State. Available online: https:/ / www.state.gov/supporting-a-healthy-sustainable-mekong-river (accessed on 31 December 2021).

165. U.S. Embassy in Thailand. Available online: https://th.usembassy.gov/remarks-david-stilwell-assistant-secretary-at-indopacific-conference-on-strengthening-transboundary-river-governance/ (accessed on 31 December 2021).

166. Stillwell, D.R. The Mekong-U.S. Partnership: Why the Mekong Region Matters to the United States, ASEAN, and the Indo-Pacific. J. Greater Mekong Stud. 2020, 4, 11-15.

167. Embassy of the People's Republic of China in the Kingdom of Cambodia. Available online: http://kh.china-embassy.org/eng/ fyrth_3/t1813183.htm (accessed on 31 December 2021).

168. Ministry of Foreign Affairs of the People's Republic of China. Available online: https://www.fmprc.gov.cn/eng/xwfw_665399 /s2510_665401/2511_665403/202012/t20201214_693532.html (accessed on 31 December 2021).

169. Embassy of the People's Republic of China in the United States of America. Available online: http:/ /www.china-embassy.org/ eng/fyrth/t1772006.htm (accessed on 31 December 2021).

170. U.S. Mission to ASEAN. Available online: https:/ / asean.usmission.gov/secretary-pompeo-to-participate-in-virtual-u-s-aseaneas-arf-mekong-u-s-partnership-foreign-ministers-meetings-september-9-11/ (accessed on 31 December 2021).

171. Basist, A.; Williams, C. Mekong River Wetness Anomalies in the 2019 Monsoon Season; Eyes on Earth: Alexander, NC, USA, 2020.

172. Basist, A.; Williams, C. EOE Report on the Improvement of the Wetness Index in Discharge Models along the Upper Mekong River; Eyes on Earth: Alexander, NC, USA, 2021.

173. Stimson Center. Available online: https://www.stimson.org/2020/new-evidence-how-china-turned-off-the-mekong-tap/ (accessed on 31 December 2021).

174. Lancang-Mekong Water Cooperation Information Platform. Available online: http://www.lmcwater.org.cn/dynamic_news/20 2103/t20210316_164074.html (accessed on 31 December 2021).

175. Mekong River Commission. Mekong Drops to "Worrying" Levels, Some Sections Turning Blue-Green. Available online: https:/ / www.mrcmekong.org/news-and-events/news/pr002-12022021/ (accessed on 31 December 2021).

176. Mekong River Commission. Near-Real Time Hydrometeorological Monitoring. Available online: https://monitoring.mrcmekong. org / (accessed on 31 December 2021).

177. Planet. Available online: https://www.planet.com/stories/mekong-mainstream-at-chiang-saen-thailand-golden-t-XlhhVOaGg (accessed on 31 December 2021)

178. Lancang-Mekong Water Resources Cooperation. Available online: www.lmcwater.org.cn/water_information/regulation_ information/202008/t20200824_162706.html (accessed on 31 December 2021).

179. Ministry of Foreign Affairs of the People's Republic of China. Available online: https://www.fmprc.gov.cn/ce/cegh/eng/fyrth/ t1838011.htm (accessed on 31 December 2021).

180. Ministry of Foreign Affairs of the People's Republic of China. Available online: https://www.fmprc.gov.cn/mfa_eng/wjdt_6653 85/2649_665393/202106/t20210609_9170566.html (accessed on 31 December 2021).

181. U.S. Department of State. Available online: https:/ / www.state.gov/remarks-at-the-mekong-u-s-partnership-track-1-5-policydialogue-opening-plenary/ (accessed on 31 December 2021).

182. Earth Journalism Network. Available online: https://earthjournalism.net/opportunities/expired-opportunities/Mekong-DataJournalism-Fellowship-2021- (accessed on 31 December 2021).

183. East-West Center. Available online: https://www.eastwestcenter.org/system/tdf/private/riverconference_report_2020_final_ web.pdf?file=1\&type=node\&id=39486 (accessed on 31 December 2021).

184. State Council of the People's Republic of China. Available online: http://english.www.gov.cn/premier/news/202109/09/ content_WS6139fd94c6d0df57f98dff08.html (accessed on 31 December 2021).

185. Ministry of Foreign Affairs of the People's Republic of China. Foreign Ministry Spokesperson Hua Chunying's Regular Press Conference on 23 March 2021. Available online: https:/ /www.fmprc.gov.cn/mfa_eng/xwfw_665399/s2510_665401/2511_665403 /202103/t20210324_9170711.html (accessed on 31 December 2021).

186. Center for Social Development Studies. Available online: https://www.csds-chula.org/activityandevents/2020/7/30/eventresources-the-mekong-runs-dry-governance-in-transition-a-close-look-at-current-rules-and-geopolitics-at-play (accessed on 31 December 2021). 
187. Center for Social Development Studies. Available online: https://www.csds-chula.org/activityandevents/2020/8/7/eventresources-low-flows-drought-data-and-geopolitics-on-the-mekong-lancang-bangkok-6-august-2020 (accessed on 31 December 2021).

188. Tuo Tre News. Available online: https:/ tuoitrenews.vn/news/society/20200530/chinese-dams-withhold-water-worsen-2019 -drought-in-mekong-delta-researchers/54823.html (accessed on 31 December 2021).

189. Cambodianess. Available online: https://cambodianess.com/article/more-transparency-and-cooperation-needed-for-themekong-river-to-survive (accessed on 31 December 2021).

190. Foreign Policy. Available online: https://foreignpolicy.com/2020/04/22/science-shows-chinese-dams-devastating-mekongriver/ (accessed on 31 December 2021).

191. Bangkok Post. Available online: https:/ / www.bangkokpost.com/opinion/opinion/1960339/the-struggle-for-the-soul-of-themekong-river (accessed on 31 December 2021).

192. Stimson Center. Available online: https://www.stimson.org/2020/discussing-chinas-dams-on-the-mekong (accessed on 31 December 2021).

193. Foreign Correspondents' Club of Thailand. Available online: https://www.fccthai.com/events/mekong-update-new-evidenceof-chinas-dam-impacts-and-why-it-matters / (accessed on 31 December 2021).

194. Lancang-Mekong Water Cooperation Information Platform. Available online: http://www.lmcwater.org.cn/dynamic_news/20 2009/t20200915_163112.html (accessed on 31 December 2021).

195. Lancang-Mekong Water Cooperation Information Platform. Available online: www.lmcwater.org.cn/water_information/ regulation_information/202101/t20210105_163831.html (accessed on 31 December 2021).

196. Lancang-Mekong Water Cooperation Information Platform. Available online: http://www.lmcwater.org.cn/water_information/ regulation_information/202108/t20210802_164635.html (accessed on 31 December 2021).

197. Stimson Center. Available online: https://www.stimson.org/2021/mekong-dam-monitor-alerts-and-advisories / (accessed on 31 December 2021).

198. U.S. Embassy \& Consulate in Thailand. Available online: https://th.usembassy.gov/the-mekong-u-s-partnership-heroes-seriesbuilding-a-bright-future-for-the-mekong/ (accessed on 31 December 2021).

199. Stimson Center. Available online: https://www.stimson.org/project/mekong-dam-monitor/ (accessed on 31 December 2021).

200. China Daily. Available online: http://www.chinadailyasia.com/article/141177 (accessed on 31 December 2021).

201. Lancang-Mekong Water Cooperation Information Platform. Ministry of Water Resources of China: Water Resources Cooperation as a Bright Spot of the Lancang-Mekong Cooperation. Available online: http:/ / www.lmcwater.org.cn/dynamic_news/202009/t2 0200915_163125.html (accessed on 31 December 2021).

202. Lancang-Mekong Water Cooperation Information Platform. Interview with Chinese Official about Hydropower Issues on the Lancang-Mekong River. Available online: http:/ / www.lmcwater.org.cn/dynamic_news/202101/t20210107_163840.html (accessed on 31 December 2021).

203. Hou, S.; Tian, F.; Lu, Y.; Ni, G.; Lu, H.; Liu, H.; Wei, J. Flood control effect of joint operation of reservoirs in Lancang-Mekong River basin (澜沧江-湄公河流域水库联合调度防洪作用). Adv. Water Sci. 2021, 32, 68-78.

204. Li, Y.; Wang, J.; Tang, X.; Luo, X.; Tan, X.; Wang, G. Characteristics of Runoff Variation and Seasonal Pattern of Lancang-Mekong River in the Context of Environment Change (变化环境下澜沧江-湄公河流域径流演变及年内分配特征). Res. Soil Water Conserv. 2021, 28, 141-148.

205. Sun, Z.; Chen, Z.; Deng, Z.; Dai, Y.; Xu, D. Relation between sediment mass flux and volume runoff under natural condition of Lancang River (澜沧江自然条件下输沙质量通量与体积径流量的关系). J. Zhejiang Univ. 2019, 53, 932-939.

206. Lu, Y.; Tian, F.; Guo, L.; Borzì, I.; Patil, R.; Wei, J.; Liu, D.; Wei, Y.; Yu, D.J.; Sivapalan, M. Socio-hydrologic modelling of the dynamics of cooperation in the transboundary Lancang-Mekong River. Hydrol. Earth Syst. Sci. 2021, 25, 1883-1903. [CrossRef]

207. Mekong River Commission. Procedures for Data and Information Exchange and Sharing; Mekong River Commission Secretariat: Vientiane, Laos, 2001.

208. Guo, G. Environmental Security and the Lancang-Mekong River Basin: Conflicting Interests of Stakeholders in China. FESS Issue Brief 2007, 8, 1-12.

209. Mekong River Commission. Available online: https://www.mrcmekong.org/news-and-events/op-ed/op-ed-low-river-levelscaused-by-extreme-low-rainfall/ (accessed on 31 December 2021).

210. Mekong River Commission. Available online: https://www.mrcmekong.org/news-and-events/news/the-effects-of-chinesedams-on-water-flows-in-the-lower-mekong-basin/ (accessed on 31 December 2021).

211. Lee Kuan Yew School of Public Policy. Available online: https://lkyspp.nus.edu.sg/cag/events/details/asean-faces-the-futurewhat-to-expect-from-the-27th-asean-regional-forum (accessed on 31 December 2021).

212. Tomas-Vilamayor, S.; Avagayan, M.; Firlus, M.; Helbing, G.; Kabakova, M. Hydropower vs. fisheries conservation: A test of institutional design principles for common pool resource management in the lower Mekong basin social-ecological system. Ecol. Soc. 2016, 21, 324-352. [CrossRef]

213. Daoudy, M. Asymmetric Power: Negotiating Water in the Euphrates and Tigris. Int. Negot. 2009, 14, 361-391. [CrossRef]

214. Mekong Institute. Available online: http://fad.onwr.go.th/file/mlc/03_MLC\%20WP2_Datasharing_ANNEX\%20J.pdf (accessed on 31 December 2021). 